\title{
HEALTH CARE COST CONTROL BY THIRD PARTY PAYORS: FEE SCHEDULES AND THE SHERMAN ACT
}

\author{
D. WARD KALLSTROM*
}

TABLE OF CONTENTS

I. Introduction ............................... 646

II. Fee Schedules and the Cost Containment

PROBLEM..................................... 647

A. The Failure of Market Incentives.............. 647

B. Service Plans and Private Carriers............... 649

C. Utilization Review and Closed Panels............. 652

III. The Antitrust Threat......................... 654

A. The Sherman Act's Ban on Price Fixing.......... 654

B. The Sherman Act's Applicability to Medical Fee Schedules .................................. 657

IV. Avoiding Antitrust Liability .................. 659

A. The Ancillary Restraint Doctrine ............... 659

B. The Rule of Reason and Maximum Price Restraints ................................ 665

C. Antitrust Experience with Prepaid Drug and Legal Service Plans ................................... 669

1. Prepaid Drug Plans....................... 669

2. Prepaid Legal Service Plans ............... 674

* J.D. 1977, Duke University School of Law. Member of California Bar.

The author owes a great intellectual debt to Professor Clark Havighurst, under whom the author studied while in law school.

THE FOLLOWING CITATIONS WILL BE USED IN THIS ARTICLE:

Hearings on Competition in the Health Services Market Before the Subcomm. on Antitrust and Monopoly of the Senate Comm. on the Judiciary, 93d Cong., 2d Sess. (1974) [hereinafter cited as Hearings on Competition];

J. Krizay \& A. Wilson, The Patient as Consumer: Health Care Financing in the UNITED STATES (1974) [hereinafter cited as KRIZAY \& WiLsoN];

Havighurst, Health Maintenance Organizations and the Market for Health Services, 35 LAw \& CONTEMP. PROB. 716 (1970) [hereinafter cited as Havighurst, HMO's];

Meeiks, Antitrust Aspects of Prepaid Legal Services Plans, 1976 AM. B. Foundation ReSEARCH J. 855 [hereinafter cited as Meeks];

Note, The Organized Bar and Prepaid Legal Services-An Antitrust Analysis, 1975 WASH. U.L.Q. 1011 [hereinafter cited as Washington Note]. 
V. Separating Fee Schedules from Provider

Control: The Crucial Limitation ............... 678

VI. The McCarran-Ferguson Exemption and

Professionally Sponsored Fee Schedules ........ 684

VII. Relative Value Schedules: A Permissible

Approach to Health Care Cost Control......... 689

A. Why Relative Value Schedules are Desirable ...... 689

B. Antitrust Attack on Medical Society-Designed Relative

Value Schedules: The Trade Association Cases ..... 691

C. Relative Value Schedules Designed by Insurers-A

Permissible Alternative ......................... 695

VIII. CONCLUSION .................................... 696

\section{INTRODUCTION}

Schedules of professional fees can either help or hinder the cause of cost containment in medical care. On the one hand, fee schedules are a form of price fixing, potentially vulnerable to attack under the Sherman Act as depriving the public of the benefits of price competition. On the other hand, fee schedules may limit the prices which providers of health care may charge for their services in a market made noncompetitive by the presence of health insurance. This Article discusses fee schedules and their relation to other cost containment strategies available in the private sector. It argues that insurer-imposed fee schedules, when used in combination with utilization review and closed-panel delivery models, can be effective in combating the price escalation that now plagues the third party payment system.

This Article also argues that the Sherman Act does not proscribe the use of fee schedules by commercial insurance companies as a means of obtaining cost control. The analysis covers the applicability to insurer-initiated fee schedules of the antitrust exception for "ancillary" restraints of trade, drawing upon the analogous antitrust experience with prepaid pharmaceutical and legal service plans, and the McCarran-Ferguson Act's antitrust exemption for "the business of insurance." 1 Fee schedules employed by commercial carriers are contrasted with the less defensible "usual, customary and reasonable fee" approach traditionally employed by Blue Shield service plans. This Article concludes that maximum fee schedules, including the use of relative value scales imposed by insurers to control costs, are legal so long as

1. 15 U.S.C. $\$ \S 1011-1015$ (1976). 
they are structured to prevent providers of care from using them as a device for fixing prices. In addition, a type of fee schedule, the relative value scale, ${ }^{2}$ is examined. Relative value scales, which have been used for some time by the medical profession and insurers, describe the numerical relationship between the values of different services as they are actually being charged by the professional community. ${ }^{3}$ The schedule measures relative value, not price; no price is determined until the practitioner applies his own charge multiplier, or "conversion factor," to the relative value index number stated. ${ }^{4}$

\section{Fee Schedules and the Cost Containment Problem}

\section{A. The Failure of Market Incentives.}

The customary practice in the medical industry is for doctors and hospitals to submit bills and for insurance companies to pay them. ${ }^{5}$ Health care costs are rising precipitously because under this customary practice there are no incentives for restraint. ${ }^{6}$ Doctors, knowing that they will be paid what they charge, have no incentive to control the amount and the price of services. ${ }^{7}$ Insured patients are ineffective in limiting the care they receive; aside from usually insignificant deductibles and coinsurance obligations under their policies, all care is essentially "free" from their perspective. ${ }^{8}$ In the long run, of course, insureds

2. See, e.g., California Medical Association, 1969 Relative Value Studies. See also National Association of Blue Shield Plans, Blue Shield Professional Services INDEX (1964).

3. See California Medical Association, supra note 2, at 3, 6; Carlova, The Attack on RVS: A Step Closer to Fee Control, Med. Econ., April 19, 1976, at 31, 35.

4. See California Medical Association, supra note 2, at 7, 119; Blaine, A Relative Value Index for Lawyer's Services, 53 ILL. B.J. 1006, 1007-09 (1965).

5. See Havighurst, Regulation of Health Facilities and Services by "Certificate of Need," 59 VA. L. REv. 1143, 1157 (1973).

6. HeW Public Health Service, Forward Plan for Health FY 1978-1982, 34 (1976); Posner, Regulatory Aspects of National Health Insurance Plans, 39 U. CHI. L. Rev. 1, 5 (1971). It has been noted that "[w]ith an estimated 80-90 percent of Americans having at least some public or private health insurance, and well over half rather comprehensively covered, the medical care system has almost a blank check for its services." McClure, The Medical Care System under National Health Insurance: Four Models, 1 J. Health Pol., Pol'y \& L. 22, 33-34 (1976); see Newhouse \& Taylor, How Shall We Pay for Hospital Care?, 23 PUB. INTEREST 78, 80-83 (1971). See also KrIZAY \& WILson 111-15; Feldstein, The Medical Economy, ScIENTIFIC AM., Sept. 1973, at $151,153-55$.

7. See Reinhardt, Alternative Methods of Reimbursing Non-institutional Providers of Health Services, in Conference on Regulation IN the HeAlth INDUSTRY OF THE INSTITUTE of Medicine of the National Academy of Sciences, Controls on Health Care 139, 148-49 (1975).

8. "[T]he current type of costly medical care does not correspond to what consumers (and 
do pay for this care through higher premiums, but it is irrational for any given patient to refrain from drawing on the collective fund at the moment the utilization decision is made, especially when nothing prevents others from exploiting the insurance fund.

Under the present system, only the third party payor has any immediate incentive to control costs. ${ }^{9}$ Since it must meet all charges from a premium pool that is fixed in advance, the third party stands to gain as those charges are kept down. Insurers, however, have not responded to this incentive. ${ }^{10}$ Instead, commercial insurers have acquiesced in health care cost inflation by simply increasing premiums to meet expected increases in costs. Competition has not induced different behavior.

Cost control can be introduced into this system by one of two broad approaches: by governmental fiat-what Charles L. Schultze has called the "command-and-control responses"11—or by adjusting private market incentives. This Article is premised on the notion that the

their physicians too) would regard as being appropriate if their choices were not distorted by insurance." Feldstein, supra note 6, at 151, 154. Interestingly, despite the rising costs and increasing availability of health insurance and of health care, patients' out-of-pocket costs did not rise in 1950-1969 as a percentage of disposable income. KRIZAY \& WILSON 4. In large part, this situation is traceable to the group employment plans which dominate the third party market. Under these plans, the insured looks upon health care as a fringe benefit of employment and seldom knows its true cost. Id. 30-32.

9. There appear to be several reasons why a fiscal intermediary might want to impose price ceilings on providers. First and foremost, controlling medical cost inflation could reverse the pattern of financial loss that has plagued many health insurance plans for a number of years. See Private Health Insurance in 1974: A Review of Coverage, Enrollment, and Financial Experience, 39 Soc. SeC. Bull., Mar. 1976, at 3-22; The Sky's the Limit on Health Care Costs, Bus. WeEk, May 26, 1975, at 72, 74; What Price Health Care? The Problem of Cost Containment, in Proceedings of the National Leadership Conference on AMerica's Health Policy 38, 42 (1976).

Second, the efficient cost reducer could expect to capture a larger segment of the health insurance market by reducing the price of his coverage to consumers below that of his competition. See Hearings on Competition, pt. 2, at 1049.

Third, an aggressive program of cost control by insurers would take the pressure caused by health care inflation off the insurance industry, see H. SOMERs \& A. SOMERs, Doctors, PATIENTS AND HEALTH INSURANCE 405 (1961); Bodenheimer, Cummings \& Harding, Capitalizing on Illness: The Health Insurance Industry, 4 INT'L J. HEALTH SERvices 583 (1974), and place it upon those best able to prevent cost increases-the hospitals and the doctors. Cf. S. LAW, BLUE CROssWhat Went Wrong? 117 (1974); H. Somers \& A. SoMERs, supra at 405-06.

Finally, a cost control program would make medical insurance plans more consistent with the standard and sensible insurance practice of seeking to restrict payouts.

10. In a few pilot plans, chiefly sponsored by labor unions and other employment groups, third parties are experimenting with fee controls over providers or care. See Webster County Memorial Hosp., Inc. v. United Mine Workers Welfare \& Retirement Fund of 1950, 536 F.2d 419 (D.C. Cir. 1976); Council on Wage and Price Stability, Employee Health Care Benefits: Labor and Management Sponsored Innovations in Controlling Cost, 41 Fed. Reg. 40,298, 40,310, 40,317-18 (1976).

11. Schultze, The Public Use of Private Interest, HARPER's, May 1977, at 43, 44. 
second alternative is more likely to succeed. ${ }^{12}$ Given the chance to run their natural courses, market incentives should draw insurance companies into the business of offering cost containment as a service to health care consumers. That insurance companies have not already undertaken to provide this service indicates that market forces have not been permitted to operate freely. At every turn in the road to cost-control innovation insurers have been faced with barriers, often in the form of restrictive practices of organized medicine or of legislation created at the behest of the medical establishment. ${ }^{13}$

Fee schedules are one of many innovations that insurers might employ to bring down the barriers that have been erected to protect the present third party payment system. To understand how fee schedules would work to correct the pressures that push costs upward, it is necessary to view them against the backdrop of traditional health care financing.

\section{B. Service Plans and Private Carriers.}

The market for health insurance has long been dominated by two types of third party payors: Blue Cross and Blue Shield plans ("service plans") and private commercial carriers. The service plans are nonprofit, tax-exempt organizations which contract directly with providers of care to obtain services required by their subscribers, often at a price discount. ${ }^{14}$ Private carriers, on the other hand, have no direct dealings with providers but instead contract with their subscribers to indemnify

12. For a discussion of why a national health insurance scheme is unlikely to cure the ills that afflict the third party system, see Feldstein, supra note 6, at 151, 158-59; Havighurst, Regulation of Health Institutions, in CONFERENCE ON REGULATION IN THE HEALTH INDUSTRY OF THE Institute of Medicine of the National ACADEMY OF Sciences, Controls on Health CARE 75, 79-80 (1975); Posner, supra note 6; Reinhardt, supra note 7, at 151. See also Hearings on Competition, pt. 3, at 1583-84. For the argument that a monolithic national regulatory system may be an unwise development in the health care industry generally, and hence that its impact should be minimized, see Havighurst, Federal Regulation of the Health Care Delivery System: A Foreward in the Nature of a "Package Insert," 6 U. Toledo L. REv. 577 (1975); Havighurst, supra note 5, at 1143, 1178-1215 (1973); Star, A National Health Program: Organizing Diversity, in INSTITUTE of Society, Ethics and the Life Sciences, Hastings Center Report 11, 12-13 (1975).

13. See, e.g., Ellwood, Altematives to Regulation: Improving the Market, in CoNFERENCE ON Regulation In the Health Industry of the Institute of Medicine of the National ACAdemy of Sciences, Controls on Health CARe 49, 54-55 (1975); Goldberg \& Greenberg, The Effect of Physician-Controlled Health Insurance: U.S. v. Oregon State Medical Society, 2 J. HeAlth Pol., POL'y \& L. 48 (1977); Havighurst, Controlling Health Care Costs: Strengthening the Private Sector's Hand, 2 J. Health Pol., Pol'y \& L. 471, 488-89 (1977); Kissam \& Johnson, Health Maintenance Organizations and Federal Law: Toward a Theory of Limited Reformmongering, 29 VAND. L. REV. 1163, 1167, 1203-32 (1976).

14. See KRIZAY \& WILSON $5,41-42$. The Blues collectively cover about $40 \%$ of the insured population. 
them for expenses they incur. ${ }^{15}$

The Blue service plans originated as creatures of the hospital associations, in the case of Blue Cross, and state medical societies, in the case of Blue Shield. ${ }^{16}$ Although provider control has become attenuated, it still exists in some plans. ${ }^{17}$ Typically, the Blues reimburse hospitals for their costs and physicians for their reasonable professional charges, as determined under a "usual, customary and reasonable fee" formula (UCRF). Thus, the Blue Shield plans usually agree to pay participating physicians their "usual" fee up to a stated percentile of the range of fees that are "customary" for a particular procedure in the area, with "reasonable" increases if there are complications. ${ }^{18}$

One possible effect of the UCRF system is to encourage physicians to raise their "usual" charges to the maximum reimbursable level, then to raise their "customary" fees more or less in unison when the service plan recomputes. its UCRF schedule for the forthcoming year. ${ }^{19}$ Although ostensibly serving as a maximum price ceiling, the UCRF could thus easily become a minimum price floor and could allow doctors, with only casual collusion, to ratchet costs upward each time the UCRF schedule is revised. Efforts by service plans to resist this ratchet effect by not releasing information on maximum reimbursement levels may fail because providers can determine the maximum levels either by exchanging information with each other or through simple trial and error. Historically, under some Blue Shield plans, providers have agreed to accept the UCRF as full payment for patients in lower income brackets, while remaining free to charge more for patients who are better able to pay. Thus, Blue Shield plans, even though in a position to control costs because of their contractual relationship with prov-

15. Id. $41,97,115$. There are more than 1,000 private health insurance carriers in the United States, most of them life insurance companies, collectively managing over $50 \%$ of the health insurance market. Their market power is well dispersed; the 20 largest insurance firms account for only 73\% of the commercial market. Id. 5. However, the "big four" commercials- Aetna, Travelers, Prudential and Metropolitan-control, between them, $20 \%$ of the national health insurance market. Hearings on National Health Insurance Before the House Comm. on Ways and Means, 93d Cong., $2 d$ Sess., pt. 4, at 1542-43 (1974).

16. See Havighurst, HMO's 769-70.

17. Provider domination of Blue plan boards of directors continues even though their percentage representation on the boards has been declining in recent years. See GoverNOR's TASK ForCE ON HEALTH CARE, FINAL REPORT 106-07 (Ohio 1973); S. LAw, supra note 9, at 6-13, 25-30 (1974); What's Blue Shield Up To Now?, MED. ECON., Sept. 6, 1976, at 92, 102.

18. KRIzAY \& WILSON 41, 115-16.

19. See id. 115-16. For a theoretical discussion of the effect of UCRF on costs, see Frech \& Ginsburg, Imposed Health Insurance in Monopolistic Markets: A Theoretical Analysis, 13 EcoN. INQUIRY 55, 67-69 (1975). An empirical study of the ratchet effect of UCRF pricing is presently being conducted by David Eisenstadt, Assistant Professor of Economics at the University of Missouri at Columbia. 
iders, may have in fact contributed to cost escalation. ${ }^{20}$

Private carriers have not had the direct link with providers that the service plans have enjoyed, and they have therefore not been strategically placed to work aggressively towards cost control. The tax-exempt status and price discounts enjoyed by the service plans put the private carriers at some competitive disadvantage in any event, and they have been reluctant to risk the displeasure of physicians. ${ }^{21}$ They have thus generally followed the leadership of the service plans in accepting UCRF fees, further contributing to the inflation cycle. ${ }^{22}$ Moreover, efforts by private carriers to resist excessive charges in a systematic way have met with stiff opposition from the medical profession, which has insisted that fee issues be submitted for professional "peer review."23 Nevertheless, insurance companies have begun to express substantial interest in the fee schedule approach to controlling health care cost inflation. ${ }^{24}$

Because commercial insurers normally do not pay providers directly but instead indemnify their insureds for covered services, their use of fee schedules to contain costs would require writing a new and more limited type of insurance coverage. Subscribers would be covered in full for their medical expenses only if they accepted care from participating providers. Participating providers-possibly organized in a group practice-would agree in advance to accept the insurer's fee schedule in determining their charges. If the subscriber obtained treatment from a nonparticipating provider, he would either not be indemnified at all or would be indemnified on a less advantageous basis, such as for some specified fraction of the bill. The insurance carrier might even offer alternative plans at differing costs, in an effort to match effciency and quality of care to the subscriber's ability and willingness to pay. ${ }^{25}$ Insured consumers of health care, in enrolling in a plan or in choosing between participating and nonparticipating providers, would for the first time be faced with choices reflecting relative fees. Likewise, providers would be faced with competitive pressure to provide services

20. HEW Public Health SeRvice, supra note 6, at 34. See also N.Y. Times, Aug. 4, 1975, at 40, cols. 6-7; Soaring Cost of Medical Care, U.S. NEWS \& WORLD REP., June 16, 1975, at 52, 53.

21. See text accompanying note $70 \mathrm{infra}$.

22. Havighurst, supra note 5 , at 1157.

23. See Goldberg \& Greenberg, supra note 13, at 63-65; Rosenberg, He Challenged Aetna's Hard-Line Fee Policy-and Won, MED. Econ., Sept. 11, 1972, at 31.

24. See, eg., Bailey, Rising Health Care Costs-A Challenge to Insurers, 8 NAT'L J. 608, 609 (1970); What Price Health Care? The Problem of Cost Containment, in Proceedings of tHe NAtional Leadership Conference on AMerica's Health Policy 38, $41-43$ (1976).

25. See Newhouse \& Taylor, supra note 6 , at $78,87-89$. 
more efficiently and to control their prices in order to obtain patients. ${ }^{26}$

\section{Utilization Review and Closed Panels.}

To be truly effective, fee schedules should be coupled with other insurer-instituted cost-control measures. Utilization review is a natural concomitant of the use of fee schedules. Without some sort of check on utilization, the savings gained by a ceiling on what can be charged for specific procedures could easily be lost as providers order more procedures or more visits. ${ }^{27}$ To combat this tendency, insurers might require that providers submit to a review mechanism similar to the Professional Standard Review Organization (PSRO) program-the federal government's vehicle for curbing over-utilization of services under Medicare and Medicaid. ${ }^{28}$ Once again the mechanics of obtaining provider cooperation would probably require differentiating coverage between participating and nonparticipating doctors. Physicians participating in the insurer's program could be required to obtain advance approval of some hospital admissions and some costly procedures as a condition of payment so that only medically necessary-and not merely possibly desirable - care would be paid for by the plan. Second opinion requirements might also be employed as a precondition for coverage of surgery. ${ }^{29}$ While necessitating considerable change in medical practice and forcing the physician to concern himself with the limitations of insurance coverage, such arrangements would greatly enhance assurances that the plan reimburses only essential care and that other care is either not provided at all or is performed at the patient's personal expense. Educating consumers to such selective coverage would undoubtedly be difficult, but lower insurance premiums would encourage consumers to consider its value. ${ }^{30}$

26. See Ellwood \& McClure, Memorandum on Health Delivery Reform 2 (unpublished paper, Interstudy, rev. Nov. 17, 1976).

27. Insurers could take an active role in maintaining good quality care as well as lower price by requiring participating providers to submit to quality-assurance regulation, perhaps on the PSRO model, and by undertaking malpractice litigation on behalf of insured patients. By introducing such controls, insurance companies could short-circuit the quality issue which physicians and hospitals often raise as a smokescreen to oppose controls on cost and utilization. See Bauer \& Densen, Some Issues in the Incentive Reimbursement Approach to Cost Containment: An Overview, 31 Med. CARE REv. 61, 90 (1974). Good care does not equate to the most expensive care. See also Havighurst, supra note 13, at 479-81; McClure, supra note 6, at 28 (the rapidly rising costs of health care have not resulted in discernible improvement in health levels).

28. See Bailey, supra note 24, at 609.

29. The hospital associations in Oregon in the 1930's used prior approval as well as utilization on review. See Goldberg \& Greenberg, supra note 13, at 50-55.

30. Some insurers are presently experimenting with second opinion requirements and utilization on review, apparently with striking success. See Council on Wage and Price Stability, supra 
Intimately related to fee schedules and utilization review is the closed-panel concept. Insurers can reduce premiums without reducing their insureds' basic protection only if their insureds can obtain essential medical treatment at reduced costs. That guarantee is possible only if insurers can differentiate among providers in writing coverage, inducing insureds to seek care from those providers who have contracted in advance to abide by the insurer's various cost-containment initiatives.

Closed-panel arrangements can take a wide variety of forms, several of which have recently been identified by the term "health care alliance." ${ }^{31}$ Under the alliance model, a closed panel of providers, perhaps including one or more hospitals, administers care on a traditional fee-for-service basis. Subscribers, who may obtain care only from doctors within the plan, pay premiums based upon the cost experience of the participating providers. Doctors and patients thus share the benefits of the doctors' greater efficiency. Whatever the merits and deficiencies of the various possible closed-panel models, they could best be worked out in the competitive marketplace, not in abstract discussion. The significant point is that closed panels are central to the goal of reintroducing competition in the market for insured health services. Insurerorganized closed panels seem easier to organize than most "health maintenance organizations" (HMOs), which they somewhat resemble, ${ }^{32}$ and more competitive than the even more closely analogous "independent practice associations" (IPAs), which are usually sponsored

note 10, at 40,298, 40,300-03, 40,319-20; Peck, Peer Review, Courtesy Goodyear Tire \& Rubber, MED. ECON., Apr. 4, 1977, at 31. See also Havighurst, supra note 13, at 484-85.

31. See Ellwood \& McClure, supra note 26; Reynolds, A New Scheme to Force You to Compete for Patients, MED. Econ., Mar. 21, 1977, at 23.

A Health Care Alliance (HCA) would be organized by an insurer, and would consist of a limited set of hospitals and doctors who have been designated by the insurer to function as an economic unit in delivering comprehensive medical care to consumers who have expressed a preference for the alliance plan. Each community could have several HCAs, and any insurer could set up more than one HCA if he cared to. But in order to attract consumers, each insurer would attempt to select for participation in his preferred HCAs, providers who could provide good quality care at a reasonable cost, and especially providers who make conservative use of the hospital . . .

Providers could participate in one or more HCAs if they cared to, but would have to negotiate reimoursement arrangements separately with each $\mathrm{HCA}$.

Ellwood \& McClure, supra note 26, at 4 (footnote omitted); cf. Lavin, "We Ask the Wrong Questions About National Health Insurance," MED. Econ., Aug. 8, 1977, at 35.

32. For discussion of HMOs, see generally KRIZAY \& WILSON 125-39; H. SOMERS \& A. SOMERS, supra note 9, at 344-58; Havighurst, HMO's 716; Phelan, Erickson \& Fleming, Group Practice Prepayment: An Approach to Delivering Organized Health Services, 35 LAW \& CONTEMP. PROB. 796 (1970); authorities cited in note 13 supra. HCAs resemble HMOs in that both arrangements offer services by a relatively small number of physicians and both achieve administrative economy through unusually close insurer-provider relations. However, since HCA doctors would be paid on a piece-work basis rather than a flat salary, they would have greater incentives than HMO doctors to provide efficient service. 
by organized medicine. ${ }^{33}$ Most important, closed panels under insurer sponsorship are a natural evolution from customary insurance plans and seem to be the shortest step to reorganizing health care delivery and imposing market checks on provider spending of consumer-contributed resources.

Under closed-panel systems, insurance companies for the first time could become involved in directly policing the fees charged for individual services. Fee levels and the standards employed in utilization review (which simply defines plan coverage and does not purport to prescribe good medical practice) might vary depending upon the premiums charged and the insurance contract. Fee schedules and closed panels would work in tandem to match consumers and providers of care on the basis of the prices acceptable to each. Insurance companies under such a scheme would be providing to consumers the long neglected service of cost containment. To society, the insurers would be providing the service of creating and maintaining a market in which trade-offs between price, quality and the desire for insurance coverage govern the allocation of health services.

Before this market can come into being, however, certain legal obstacles must be surmounted. Restrictive state legislation, such as socalled "Blue Shield laws" requiring physician dominance or approval of all health financing plans, prohibitions against closed panels, and specific insurance coverage requirements must be overcome. In addition to these state restrictions, fee schedules cannot be imposed on doctors unless the schedules are free from the strictures of the antitrust laws. $^{34}$

\section{The Antitrust Threat}

\section{A. The Sherman Act's Ban on Price Fixing.}

The branch of antitrust law most likely to constrain the formation and implementation of fee agreements between health care insurers and providers is the prohibition against price fixing. ${ }^{35}$ Section one of

33. See notes $144-46$ infra and text accompanying notes 144-57 infra.

34. Commercial insurers have expressed interest in the fee schedule approach to cost control, see text accompanying note 24 supra, but they are wary of possible antitrust liability; some have even requested an exemption from the antitrust laws as a condition precedent to bringing price restraints to bear against providers. See text accompanying note 217 infra.

35. Other aspects of antitrust law that may touch upon insurer-provider fee arrangements are those relating to monopoly and monopsony power, exclusive dealing arrangements and group boycotts. Monopsony questions would arise whenever an insurer possessing enough market power to control prices or exclude competition exercises that power by securing fee arrangements with providers. See notes 71-72 infra and accompanying text, and text accompanying note 94 infra. 
the Sherman Act makes unlawful "[e]very contract, combination . . ., or conspiracy, in restraint of trade or commerce among the several states." ${ }^{36}$ Despite this seemingly all-inclusive language, only some types of agreements "in restraint of trade" have been found to be so anticompetitive in purpose or effect that they have been denounced as illegal per se. In cases not involving practices previously declared to be per se violations, the courts employ a "rule of reason" and will tolerate otherwise useful commercial contracts even though they embody re-

Group boycotts and exclusive dealing usually arise as violations of section three of the Clayton Act, 15 U.S.C. $\S 14$ (1976), which probably does not pertain to professional service payment arrangements because its concern is with the "sale of goods." However, the Federal Trade Commission (FTC) has the power to attack practices which offend the principles of section three even though there may be no technical violation, and the Sherman Act's "contract, combination or conspiracy in restraint of trade" language, 15 U.S.C. $\S 1$ (1976), would reach these practices as well. See FTC v. Brown Shoe Co., 384 U.S. 316, 321, 322 (1966); FTC v. Motion Picture Advertising Serv. Co., 344 U.S. 392, 394-95, 397 (1953).

Group boycotts, or concerted refusals to deal, would most likely arise in the health insurance context if insurers agreed not to deal with providers who are unwilling to accede to their fee contract terms, or vice versa. Conceivably such a boycott could be saved if its purpose and effect were not clearly anticompetitive, see, e.g., De Filippo v. Ford Motor Co., 516 F.2d 1313 (3d Cir.), cert. denied, 423 U.S. 912 (1975) (concerted action by automobile dealers to prevent auto manufacturer from granting dealership on special terms not available to other dealers did not violate section one), or if it were reasonably ancillary to a permissible joint venture, see C. KAYSEN \& D. TORNER, ANTITRUST POLICY: AN ECONOMIC AND LEGAL ANALYSIS 47, 146 (1959). But generally concerted refusals to deal fall under a virtual per se rule. See, e.g., Klor's, Inc. v. Broadway-Hale Stores, Inc., 359 U.S. 207 (1959). And a combination to boycott can be inferred from parallel action in some instances even where no overt expressions of agreement are made. See, e.g., Interstate Circuit, Inc. v. United States, 306 U.S. 208 (1939).

It would not be surprising to see exclusive dealing arrangements spring up in insurer-provider contracts; either the provider would promise to treat only patients covered by a particular fiscal intermediary, or the carrier would agree not to send insured patients to rival hospitals or physician specialists. The legality of such agreements is determined by a rule of reason inquiry into their purposes and into the extent of market foreclosure effected by them. See Standard Oil Co. v. United States, 337 U.S. 293, 306-10 (1949); Pacific Coast Agricultural Export Ass'n v. Sunkist Growers, Inc., 526 F.2d 1196 (9th Cir. 1975), cert. denied, 425 U.S. 959 (1976). Exclusive dealings could help reduce the personal and financial burdens that price bargaining could impose on providers by making relations with insurers more stable. They could also help a new entrant insurer or a failing company to secure a foothold in the market. For these reasons, they may be useful devices for use in establishing HCAs, HMOs and other new forms of health care delivery. Exclusive dealing arrangements between insurers and providers would probably be found illegal only if so substantial a portion of the relevant health care market were tied up that entry became restricted, or if the contracts themselves were unreasonable in duration or otherwise oppressive. See Travelers Ins. Co. v. Blue Cross, 481 F.2d 80, 85 (3d Cir.), cert. denied, 414 U.S. 1093 (1973) (implying that exclusive dealing contract between hospital and Blue Cross plan, insuring $51 \%$ of local population and covering $62 \%$ of all insured hospital days, would violate antitrust laws). It is worth noting, however, that the Supreme Court has shown a propensity in recent years to accept the FTC's judgment that exclusive dealing practices should be stopped in their incipiency before a substantial clog on competition occurs. See FTC v. Brown Shoe Co., 384 U.S. 316, 320-22 (1966); FTC v. Motion Picture Advertising Serv. Co., 344 U.S. 392 (1953).

36. 15 U.S.C. $\$ 1$ (1976). Section three of the Sherman Act extends the same proscriptions to the District of Columbia. Id. $\S 3$. 
straints on trade unless, considering the history and purpose of the restraint, the power structure of the market in which it developed and its likely desirable and undesirable effects, the restraint is determined to be "undue." 37 But price-fixing agreements are firmly ensconced in the prohibited categories; no inquiry as to their purposes or effects is ordinarily permissible. ${ }^{38}$

As will be discussed more fully below, not all contracts that have an effect upon price are properly considered price-fixing agreements. Obviously, where a buyer and seller agree upon a price, there is no violation, although a problem of a different kind could arise if either the buyer or the seller possessed excessive market power or could coerce the other contracting party. ${ }^{39}$ Even an arrangement between competitors that had a price-fixing aspect could escape condemnation if the price agreement could be characterized as an "ancillary" restraint-a reasonable measure necessary to achieve a desirable commercial purpose other than the repression of competition in the market. ${ }^{40}$ Finally, it is possible, though some case law suggests otherwise, that fee schedules that establish only maximum, rather than minimum, prices might be held lawful since they permit competition instead of imposing naked restraints on price. ${ }^{41}$ In these instances, especially if the factual situation were unprecedented, the rule of reason, rather than per se rules, would probably govern the outcome of a Sherman Act challenge.

37. Standard Oil Co. v. United States, 221 U.S. 1, 60 (1911); see United States v. Aluminum Co. of America, 148 F.2d 416, 427 (2d Cir. 1945). Professor Bork maintains that the rule of reason invalidates restraints only when their anticompetitive results exceed such desirable effects as in creased efficiency or availability of goods or services to consumers. See Bork, The Rule of Reason and the Per Se Concept: Price Fixing and Market Division II, 75 YALE L.J. 373, 375-76 (1966); Bork, The Rule of Reason and the Per Se Concept: Price Fixing and Market Division I, 74 YALE L.J. 775, 833-34 (1965).

38. See Albrecht v. The Herald Co., 390 U.S. 145 (1968) (vertical maximum price fixing); Kiefer-Stewart Co. v. Joseph E. Seagram \& Sons, Inc., 340 U.S. 211 (1951) (horizontal maximum price fixing); United States v. Socony-Vacuum Oil Co., 310 U.S. 150 (1940) (horizontal minimum price fixing); Dr. Miles Medical Co. v. John D. Park \& Sons Co., 220 U.S. 373 (1911) (vertical minimum price fixing).

Other restraints have also been condemned in per se terms under section one. See United States v. Topco Associates, Inc., 405 U.S. 596 (1972) (market division); Klor's, Inc. v. BroadwayHale Stores, Inc., 359 U.S. 207 (1959) (group boycotts); Northern Pacific Ry. v. United States, 356 U.S. 1 (1958) (tying arrangements).

Proof of the existence of restraints such as these is sometimes said to preclude evidence of their reasonableness. See Bork (Part I), supra note 37, at 783-811. Nonetheless, other cases suggest that a per se rule raises no more than a rebuttable presumption that can be overcome by a persuasive showing of justification. See id. at 811-28.

39. See note 71 infra and text accompanying notes 71-72, 94 infra.

40. See text accompanying notes $57-73$ infra.

41. See text accompanying notes 78-96 infra. 


\section{B. The Sherman Act's Applicability to Medical Fee Schedules.}

It was not evident until recently that the "learned professions" are subject to section one at all. In a landmark 1975 decision, Goldfarb $v$. Virginia State Bar, ${ }^{42}$ the Supreme Court finally determined that the professions do not enjoy an implied exemption from the Sherman Act. ${ }^{43}$ The case arose when the Goldfarbs, having contracted to buy a house in Virginia, contacted numerous lawyers in the hope of finding one that would search title for them cheaply. But no lawyer would quote a price below the figure prescribed in a minimum fee schedule promulgated by the Virginia State Bar. ${ }^{44}$ The Goldfarbs paid the required fee for a title search and subsequently brought a class action against the state and county bar associations seeking treble damages and injunctive relief, asserting that the fee schedule constituted price fixing proscribed by section one of the Sherman Act. The Supreme Court agreed. Relying upon the "heavy presumption against implicit exemptions" from the antitrust laws, ${ }^{45}$ the Court concluded that bar association restrictions, at least those tied as explicitly to a "business aspect" of a profession as fee schedules, fall well within the scope of the Sherman Act. ${ }^{46}$

The Goldfarb Court plainly directed its holding toward professions other than the legal profession, such as medicine and dentistry, ${ }^{47}$ and the lower courts ${ }^{48}$ and law enforcement agencies ${ }^{49}$ have been quick

42. 421 U.S. 773 (1975).

43. Several prior decisions had indicated that law and medicine might share such an exemption. See, e.g., United States v. National Ass'n of Real Estate Bds., 339 U.S. 485,490 (1950); Atlantic Cleaners \& Dyers v. United States, 286 U.S. 427, 436 (1932); FTC v. Raladam Co., 283 U.S. 643, 653 (1931); Federal Club v. National League, 259 U.S. 200, 209 (1922). But see, e.g., American Medical Ass'n v. United States, 317 U.S. 519, 528 (1943). For discussion of the Court's decades of waffling on this subject, see Bauer, Professional Activities and the Antitrust Laws, 50 Notre Dame Law. 570, 572-84 (1975); Corley \& Arnould, Professional Fee Schedules and the Sherman Act, 13 AM. Bus. L.J. 21, 27-32 (1975).

44. 421 U.S. at 775-76. The schedule recommended that lawyers charge a fee equivalent to $1 \%$ of the value of the property involved, whatever the complexity of the title records or the time required to make a thorough search.

45. Id. at 787 (citing United States v. Philadelphia Nat'l Bank, 374 U.S. 321, 350-51 (1963); California v. FPC, 369 U.S. 482, 485 (1962)).

46. 421 U.S. at 787-88. The Court carefully restricted its discussion to the fee schedule question and emphasized that nonbusiness-related restraints, even though they might otherwise be invalid under the Sherman Act, might survive if exercised among professionals. Id. at 787 n.17.

47. See id. at 787, 792 (citing antitrust cases in the medical and dental contexts to show the reach of the Sherman Act).

48. See, e.g., Ballard v. Blue Shield, 543 F.2d 1075 (4th Cir. 1976), cert. denied, 430 U.S. 922 (1977) (reversing dismissal of suit by chiropractors charging health care insurer, medical association and doctors with group boycott and attempt to monopolize); Boddicker v. Arizona State Dental Ass'n, 549 F.2d 626 (9th Cir.), cert. denied, 434 U.S. 825 (1977), cited in [1977] ANTITRUST \& TRADE REG. REP. (BNA) No. 800, at A-2 (professional society rules must serve public; if they 
to brandish Goldfarb's antitrust bludgeon against health care professionals. The courts have also extended Goldfarb to reach agreements between physicians and health insurance companies, ${ }^{50}$ although there remain substantial issues concerning whether the exemption in the McCarran-Ferguson Act of "the business of insurance" from the antitrust laws might protect some such agreements. ${ }^{51}$ Thus, although medical service minimum fee schedules of the sort proscribed by Goldfarb would certainly be subject to section one attack, ${ }^{52}$ special considerations to be discussed below would govern a Sherman Act attack on fee schedules employed in the insurance context.

Not all professional fee schedules are invalidated by Goldfarb. The price list issued by the Virginia State Bar was objectionable because it created a "fixed, minimum price floor" maintained by a discernible enforcement system. ${ }^{53} \mathrm{Had}$ it been, however, a "purely advisory fee schedule issued to provide guidelines," it would have presented a

will only suppress competition, they cannot stand); Ohio v. Ohio Medical Indem., Inc., No. C-2 75-473 (S.D. Ohio Sept. 16, 1976) (refusing to dismiss price fixing charges against medical association); Feminist Women's Health Center, Inc. v. Mohammad, 415 F. Supp. 1258 (N.D. Fla. 1976), rev'd on other grounds on rehearing No. TCA 75-186 (N.D. Fla. Nov. 18 and Dec. 3, 1976) (on appeal to Fifth Circuit) (doctors' economic boycott of abortion clinic was within the reach of Sherman Act); $c f$. Hospital Bldg. Co. v. Trustees of Rex Hosp., 425 U.S. 738, 746-47 (1976). See also Wilk v. American Medical Ass'n, No. 76 C 3777 (N.D. Ill., filed Oct. 13, 1976), cited in [1976] ANTITRUST \& TRADE REG. REP. (BNA) No. 787, at A-14 (suit by chiropractors charging group boycott and monopolization on the part of health care trade associations and officials thereof); Ohio v. Mahoning County Medical Soc'y, No. 76-1684 (N.D. Ohio, filed Aug. 24, 1976), cited in [1976] ANTITRUST \& TRADE REG. REP. (BNA) No. 784, at A-23 (suit by Ohio seeking injunction against boycott of HMO by county medical society, council of private hospital medical staffs and four doctors and against defendants' coercive tactics in preventing physicians from joining the HMO).

49. See [1973] ANTrtrust \& Trade Reg. Rep. (BNA) No. 619, at A-8 (Antitrust Division recognizes no professional exemption from antitrust laws). See also text accompanying notes 189 96 infra.

50. See, e.g., Ballard v. Blue Śhield 543 F.2d 1075 (4th Cir. 1976), cert. denied, 430 U.S. 922 (1977) (reversing dismissal of suit by chiropractors charging health care insurer, medical association and doctors with group boycott and attempt to monopolize); Anderson v. Medical Serv., No. 73-470-A (E.D. Va. Feb. 10, 1976) (fee schedule agreements between insurer and gynecologists might otherwise be within Sherman Act but were exempted by McCarran-Ferguson legislation).

51. See text accompanying notes $164-82$ infra.

52. Legal writers have disagreed on whether minimum professional fee schedules are properly subject to the usual per se rule against price fixing. Compare Bauer, supra note 43, at 584-92 (advocates rule of reason approach), with Corley \& Arnould, supra note 43, at 39-42 (fee schedules are "blatant" price fixing, hence illegal whatever their purpose). But see United States v. National Soc'y of Professional Eng'rs, 98 S.Ct. 1355 (1978) (reads Goldfarb as imposing a per se rule against professional minimum fee schedules).

53. 421 U.S. at 781-83 \& n.9. The Court emphasized that no lawyer needed to know more than the value of the property to quote a fee, that no one other than a State Bar member could lawfully perform a title search and that the State Bar's ethics opinions threatened cost-cutters with professional discipline. 
different question. ${ }^{54}$ Although purporting to be advisory, the schedule in Goldfarb exceeded a merely advisory function because it described fees for future, rather than past, transactions, because the minimum rates rose over time and because all lawyers were motivated to conform by the assurance that they would not be underbid. ${ }^{55}$ However, had there been merely "an exchange of price information without a showing of an actual restraint on trade," the Sherman Act might not have been violated. ${ }^{56}$ Moreover, the fee schedule in Goldfarb was established by a bar association, a group of competing professionals acting in concert. Nothing in the case questioned the legality of a fee schedule proposed by purchasers of legal services and assented to by the professionals acting separately. In addition, no insurance plan was present to provide a possible ancillarity or McCarran-Ferguson Act justification for a price agreement.

Before considering in detail the status of contractually arranged medical fees under section one of the Sherman Act, it will be helpful to examine the doctrines relating to ancillary restraints and maximum fees, concepts crucial to the defense of the fee schedule strategy.

\section{Avoiding ANTITRUST LiABILITY}

\section{A. The Ancillary Restraint Doctrine.}

The doctrine of ancillary restraints, which can remove from the per se category agreements affecting prices, applies where the restrictive arrangement is incidental to a dominant commercial purpose that is otherwise legitimate. Under one formulation, an ancillary restraint will be treated under the rule of reason and will be considered lawful if it "(1) is reasonably necessary to the legitimate primary purpose of the arrangement, and of no broader scope than reasonably necessary; (2) does not unreasonably affect competition in the marketplace; and (3) is not imposed by a party or parties with monopoly power."57

54. $Y d$. at 781 (emphasis added).

55. Id. at 781-82.

56. Id. at 781. This caveat seems to blunt the thrust of United States v. Container Corp. of America, 393 U.S. 333, 337 (1969), which indicated that the mere flow of specific current price information among competitors would raise a presumption of illegality. See note 209 infra and accompanying text.

57. An excellent example of an appropriate application of the ancillarity principle is suggested by Columbia Broadcasting Sys., Inc. v. American Soc'y of Composers, Authors \& Publishers, 562 F. 2 d 130 (2d Cir. 1977), discussed in 91 HARv. L. Rev. 488 (1977). That case involved a suit by the CBS television network against the American Society of Composers, Authors \& Publishers (ASCAP) challenging ASCAP's practice of issuing "blanket" licenses granting the licensee the right to publicly perform any composition in ASCAP's repertoire. The Second Circuit held that ASCAP's licensing scheme was price-fixing because the royalty received by a composer 
Fee schedules imposed by health insurers on physicians who deal with non-cost-conscious patients could easily be viewed as reasonably necessary to accomplish a legitimate commercial purpose. Limiting payouts is an accepted means of counteracting the so-called "moral hazard" posed by insurance-the consumer's tendency to ignore cost in his consumption decisions. ${ }^{58}$ The experience of the past twenty-five years has demonstrated that the social goal of reducing medical care inflation is not likely to be attained under a private third-party financing system unless direct fee constraints can be imposed upon providers of care. ${ }^{59} \mathrm{~A}$ physician possesses a degree of natural monopoly power over his patients ${ }^{60}$ and this power is enhanced by the presence of insurance which relieves patients of concern about fees or other costs. In this context, fee schedules would appear to be a reasonable means of facilitating efficient insurance protection, lowering its cost by counteracting the monopoly power of physicians.

Moreover, fee control agreements do not appear to be broader in scope than necessary to deal with the problems. Although courts might be bothered by what seems to be insurer dictation of medical and hospital charges, this would be a problem only where an insurer possessed monopsony power, ${ }^{61}$ so that providers could not sell their services in a competitive market. However, there would appear to be no practical alternative way of controlling provider charges short of government price regulation ${ }^{62}$ - a method that could be much less effective, more coercive or less attractive in other ways than private developments. The

through the blanket license is artificially fixed and represents a restraint on price competition among composers. 562 F.2d at 135-36. The court suggested that the scheme might be legal, however, if it could be demonstrated that "market necessity" made alternative marketing methods impractical. Id. at 137-38, $140 \& \mathrm{n}$.26. ASCAP, acting as middleman between the performer and distributer (CBS) may, by pooling transactions, make the market for performance of musical compositions more competitive. See 91 HARv. L. Rev., supra at 492-96. Compare Judge Taft's classic formulation of the rule in United States v. Addyston Pipe \& Steel Co., 85 F. 271, 282-83 (6th Cir. 1898), affd, 175 U.S. 211 (1899); see United States v. Sealy, Inc., 388 U.S. 350, 356 \& n.3 (1967); Timken Roller Bearing Co. v. United States, 341 U.S. 593, $597-98$ (1951); United States v. Pan Am. World Airways, Inc., 193 F. Supp. 18, 32-36 (S.D.N.Y. 1961), rev'd on other grounds, 371 U.S. 296 (1963). See also Virginia Excelsior Mills, Inc. v. FTC, 256 F.2d 538 (4th Cir. 1958) (combination of majority of excelsior producers in Virginia to stop price-cutting by naming a sole sales agent violated Sherman Act per se, but activities of the agent to lessen the producers' credit losses and standardize product grades was lawful).

58. See, e.g., Havighurst, supra note 13, at 474-75 \& n.12; Meeks 876-77 \& n.73.

59. See notes 5-13 supra and accompanying text.

60. See Hearings on Competition, pt.2, at 1039, 1580-84; S. LAw, supra note 9, at 32-33, 3841; Havighurst, HMO's 768-69; Kessel, Price Discrimination in Medicine, 1 J. L. \& Econ. 20 (1958).

61. See notes 71-72 infra and accompanying text.

62. See Hearings on Competition, pt.2, at 1039; see generally notes 60 supra \& 197 infra and accompanying text. 
problem with any cost-control approach aimed at forcing the patient to shop around, such as larger deductibles, coinsurance requirements and lower indemnification limits, is that the patient often lacks the time and the opportunity to shop around when he needs medical care and, even when he does shop around, he does not know what he actually needs. Insurer-initiated fee controls would compensate for that ignorance and for the consumer's economic weakness by developing purchasing expertise and by aggregating the buying power of greater numbers of insureds. $^{63}$

Turning to the second criterion, it is also clear that fee schedules adopted by insurance carriers would not unreasonably injure competition in the health services market. Some providers of care will object to these practices, ${ }^{64}$ but that will most likely occur because fee controls will stimulate, rather than hinder, competition in the health care delivery market. If a group or association of insurers were to combine to promulgate a fee schedule, ${ }^{65}$ or a combination of individual providers

63. See Goldberg \& Greenberg, supra note 13 , at 67-69.

64. See, e.g., Carlova, supra note 3, at 35; Edlund, Workshop on Techniques of Relative Value Studies, 25 ConN. MED. 797, 800 (1961); cf. Havighurst, HMO's 777.

Limited third party "intervention" in the doctor-patient relationship is probably an inevitable concomitant of cost control. See Hearings on Competition, pt. 2, at 1049, 1051; Council on Wage and Price Stability, supra note 10, at 40,298, 40,310, 40,318-19 (describing claims review programs instituted by several large industrial firms, each of which reports savings of up to sixfigure sums annually). Such intervention is not as shocking as some would have us believe; many of the innovations introduced into the health care delivery system in recent years-such as Medicare, Medicaid, PSROs, prospective reimbursement programs, HMOs, health planning agencies and health insurance itself (at least in the Blue plans' "service" concept)-in a very real sense "interfere" with the practice of medicine. See H. SOMERS \& A. SOMERS, supra note 9, at 406-07.

65. Combinations of insurers to achieve cost controls over recalcitrant providers of care would present significant dangers of (1) horizontal minimum price fixing as to both providers and consumers; (2) market division and customer allocation; (3) conspiracy or attempts to monopolize or actual monopolization; and (4) coercion against providers. Nevertheless, it has been suggested that in some circumstances such a combination might be proper. See GoverNoR's TASK ForCE on Health CARE, Final Report 109 (Ohio 1973) (recommending that Ohio Director of Insurance permit commercial insurers "too small to develop an adequate data base of their own" to "develop an information sharing system for review of physicians' claims"). The argument in favor of permitting such a horizontal arrangement is rooted in joint venture theory, a subdivision of the doctrine of ancillary restraints. In essence, a joint venture is a combination of several persons to accomplish jointly a "legitimate" purpose which may have anticompetitive implications; its legality turns upon a balancing of the magnitude and obvious desirability of the objective, on the one hand, and the degree to which attainment of the objective requires collaboration, against the nature, magnitude and probability of the feared restraint, on the other. See P. AREEDA, ANTITRUST ANALYSIS 360-61 (2d ed. 1974); $c f$. United States v. Penn-Olin Chem. Co., 378 U.S. 158, 176-77 (1964). Under this doctrine, competitors have been allowed to join forces to provide a public service in a new market which they could not risk entering independently. See United States v. Pan Am. World Airways, Inc., 193 F. Supp. 18, $32-36$ (S.D.N.Y. 1961), rev'd on other grounds, 371 U.S. 296 (1963) (airline and competing steamship company combined to form new corporation to provide air service to South America; held, a permissible joint venture despite parent companies' agreements not to compete with each other nor with their subsidiaries, because competitive risks 
were to join together horizontally to secure attractive fee arrangements with third parties, ${ }^{66}$ the arrangements would violate Sherman Act principles. However, where an individual carrier acting alone uses its claims data and other publicly available information to negotiate price understandings with single providers, antitrust objections would cease because the purchaser of the medical services and the seller of the services would have sufficiently adverse interests to assure competitively determined prices. ${ }^{67}$ Since competing insurers would offer contracts on differing terms based upon their own cost control experience, no unrea-

otherwise would have prevented either parent from providing the service); E. GELLHORN, ANTITRUST LAW AND ECONOMICS 229-30 (1976); $c f$. C. KAYSEN \& D. TURNER, supra note 35, at 13641 (where neither venture nor its individual participants possess substantial market power, joint venture is presumptively lawful). Case law suggests that even a horizontal minimum price fixing agreement among competitors may be sustained as a permissible joint venture if its purpose is sufficiently important and its scope sufficiently circumscribed. See United States v. Morgan, 118 F. Supp. 621, 689-91, 731, 733-39 (S.D.N.Y. 1953) (underwriters, consistent with their traditional practice, could lawfully combine to float stock issues even though they jointly possessed great market power and engaged in price fixing and market manipulation; the venture served a desirable purpose in spreading the risks of new securities issues, and the price maintenance activities were carried on for only minimal periods of time). But of. United States v. Minnesota Mining \& Mfg. Co., 92 F. Supp. 947,963 (D. Mass. 1950) (joint action by American abrasives manufacturers in establishing production subsidiaries abroad might be per se illegal due to day-to-day price fixing, joint marketing and other informational exchanges involved in running the subsidiaries).

It has also been urged that otherwise objectionable restraints should be permitted when utilized by a joint venture controlling only a nonsubstantial portion of the relevant market in an effort to enable its participants to compete more effectively. See E. GellHoRn, supra at 228-30; C. KAYSEN \& D. TURNER, supra note 35, at 138-39; Bork (Part II), supra note 37, at 391-475. But where the joint venture serves only questionable public policies and appears to merely camouflage a horizontal scheme to fix prices or divide territories, it cannot stand. See United States v. Sealy, Inc., 388 U.S. 350 (1967). Further, a basically procompetitive joint venture may be struck down where its desirable purposes could be achieved by less restrictive collaboration. See United States v. Topco Assocs., Inc., 405 U.S. 596 (1972) (territorial division agreed to by members of association of small grocers and imposed upon them by association was per se illegal under section one); Timken Roller Bearing Co. v. United States, 341 U.S. 593 (1951) (joint venture to implement a trademark licensing system violated Sherman Act where its main purpose was to divide the world market for antifriction bearings).

There is strong superficial appeal to the idea of encouraging competition in the health insurance market by allowing small firms or "new entrants" to combine their claims data for the purpose of designing relative value scales in order to win a market foothold. The important public goal of cost control would be served. If it only sought the exchange of data and not the compilation of fee schedules, a combination could contribute to diversity in insurance plans without having a measurably harmful effect on competition. But, as indicated above, there would be considerable danger that a restraint of trade would occur. A new entrant could probably establish a plan without entering a combination simply by relying upon the fee information offered by providers interested in participating in the plan. Unless it can be shown that no such less restrictive alternative is viable, a claims data exchange among insurers should be disallowed.

66. See Havighurst, supra note 13, at 481-82; see note 143 infra and accompanying text; $\mathcal{C f}$. notes 99, 103-06, 113-15 infra and accompanying text (same conclusion as to pharmacists); notes 130, 141-42 infra and accompanying text (same conclusion as to lawyers); notes 189-213 infra and accompanying text.

67. See Meeks 877. 
sonable restraint of trade would result, even though one carrier may enter into substantially identical agreements with numerous providers. ${ }^{68}$

Coercion is the third factor of the quoted ancillarity doctrine; it may present some difficulties because some private third-party carriers, especially the Blue plans, possess dominant buying (monopsony) power in some localities. ${ }^{69}$ Already, one Blue Shield plan has been charged with monopsony price fixing for having coerced druggists into participating in an oppressively unrenumerative prepaid drug plan. ${ }^{70} \mathrm{Al}-$ though it is not clear precisely what constitutes monopsony power, generally it would require that prices be set in a noncompetitive fashion so as to exclude competition and maximize the monopsonist's profits. ${ }^{71}$ In a monopsony situation, the ancillarity doctrine, if applied, should not immunize the monopsonist-insurer from potential antitrust liabil-

68. See notes 103-04, 131-33 infra and accompanying text (same results reached with respect to prepaid drug plans and legal expense insurance programs). This principle makes possible the development of HCAs, HMOs and other alternative health care delivery systems.

69. See note 161 infra.

70. See Royal Drug Co. v. Group Life \& Health Ins. Co., 556 F.2d 1375 (5th Cir. 1977), cert. granted, 98 S.Ct. 1448 (1978).

71. Monopoly power is loosely defined as "the power [of a seller] to control prices or exclude competition." United States v. E.I. du Pont de Nemours \& Co., 351 U.S. 377, 391 (1956). Monopsony power is the same thing held by a buyer. But prices need not have been fixed nor competitors excluded for such power to be found. Id. at 389. Many cases have recognized monopoly power only when a very high degree of market control-say, three-fourths or more-is demonstrated. See, e.g., United States v. American Tobacco Co., 221 U.S. 106 (1911) (95\% of U.S. cigarette sales); Standard Oil Co. v. United States, 221 U.S. 1 (1911) (90\% of national refining capacity); United States v. Aluminum Co. of America, 148 F.2d 416 (2d Cir. 1945) (90\% of national domestic market for virgin aluminum ingot); United States v. United Shoe Machinery Corp., $110 \mathrm{~F}$. Supp. 295, 307 (D. Mass. 1953), affd per curiam, 347 U.S. 521 (1954) (75-95\% of relevant market). But other cases have suggested that lesser market shares may be sufficient to support monopolization suits. See, e.g., United States v. Griffith, 334 U.S. 100 (1948) (film distribution monopoly in between $51 \%$ and $62 \%$ of 85 towns); American Tobacco Co. v. United States, 328 U.S. 781, 797 (1946) (more than two-thirds of domestic cigarette market); Pacific Coast Agricultural Export Ass'n v. Sunkist Growers, Inc., 526 F.2d 1196 (9th Cir. 1975), cert. denied, 425 U.S. 959 (1976) (45$70 \%$ of market held sufficient to support jury finding of monopoly power); United States v. Grinnell Corp., 236 F. Supp. 244, 248, 251 (D.R.I. 1964), aff'd except as to decree, 384 U.S. 563, 571 (1966) (87\% or a "predominant share of the market" is enough). Most recently, the Fifth Circuit Court of Appeals announced that there is no rigid rule requiring even $50 \%$ market control (although $20 \%$ is clearly not enough). Yoder Bros. v. California-Florida Plant Corp., 537 F.2d 1347, 1367-68 \& n.19 (5th Cir. 1976), cert. denied, 429 U.S. 1094 (1977). These cases can perhaps best be harmonized by visualizing the offense of monopolization on a sliding scale on which the degree of market domination required to make out a violation is decreased as the opprobriousness of the challenged conduct increases. See P. AREEDA supra note 65, at 258; Cooper, Attempts and Monopolization: A Mildly Expansionary Answer to the Prophylactic Riddle of Section Two, 72 Mich. L. REv. 375, 401-03, 408-18 (1974); cf. United States v. United States Steel Corp., 251 U.S. 417 (1920) (combination of 180 steel firms aggregating $80 \%$ to $95 \%$ of domestic production at time of formation, but which did not engage in brutal, predatory or unfair trade practices, and whose market share declined to $40 \%$ at time of suit, was not guilty of monopolization). 
ity. The courts should instead prevent the dominant insurer from entering into fee-limiting contracts until its market power has been diluted by smaller competitors utilizing fee agreements to capture a portion of the local health insurance market. ${ }^{72}$ Similarly, if a dominant Blue Shield plan, far from exploiting physicians, should use a liberal fee schedule to attract allegiance of providers and thereby exclude other insurers, that plan might be denied the right to use a fee schedule. This misuse of fee schedules would limit entry by other insurers with alternate plans because those insurers would have difficulty attracting providers who would be willing to accept lower fee limits, thus eliminating some desirable consumer options from the marketplace. Control of the Blue Shield plan by the local medical profession would strengthen the case for attacking both the use of overly generous fee schedules and the UCRF system. ${ }^{73}$ In both cases, providers would be taking advantage of the market power of Blue Shield to raise, rather than contain, their charges.

Despite the dangers outlined above, there are powerful reasons why certain kinds of fee schedules are desirable in the insurance context. ${ }^{74}$ They contribute to the predictability of risks ${ }^{75}$ and thereby per-

72. This result could be achieved by applying the rule against vertical price fixing. See Albrecht v. Herald Co., 390 U.S. 145 (1968); Kiefer-Stewart Co. v. Joseph E. Seagram \& Sons, Inc., 340 U.S. 211 (1951); Dr. Miles Medical Co. v. John D. Park \& Sons Co., 220 U.S. 373 (1911); notes 79-95 infra and accompanying text.

Alternatively, the same result could be attained through section two of the Sherman Act, which makes it unlawful for any person to "monopolize, or attempt to monopolize, or combine or conspire . . to monopolize any part of the trade or commerce among the several States . . ." 15 U.S.C. $\S 2$ (1976). Section two complements section one by prohibiting certain anticompetitive acts undertaken by a single person acting alone which might be illegal under section one if performed by two parties acting in combination. See Standard Oil Co. v. United States, 221 U.S. 1, 61-62 (1911).

Fee control agreements negotiated between local providers and third parties with monopsony power would call for particularly close scrutiny because of possible exclusionary implications. Secondary boycotts and exclusive dealing arrangements in such circumstances would almost certainly violate section two because they are exclusionary by definition. A per se rule might also be appropriate to condemn fee schedules in such agreements because the necessary effect would be to preserve the insurer's monopsony power. Use of monopsony power by Blue Cross and Blue Shield is especially controversial since each achieved its power not by having it thrust upon it nor through superior skill, foresight or industry, but because of special treatment by the health care providers who controlled them for the purpose of preventing competition in the health services delivery system. See text accompanying notes 152-54 infra. But see Travelers Ins. Co. v. Blue Cross, 481 F.2d 80, 85 (3d Cir.), cert. denied, 414 U.S. 1093 (1973) (Blue Cross plan which insured $51 \%$ of the population and covered $62 \%$ of all patient days covered by private commercial insurance in a 29-county area did not violate section two by negotiating $10-15 \%$ reductions in hospital rates for Blue Cross patients below those charged non-Blue Cross patients; Blue Cross owed its success to the completeness of its coverage and its willingness to take risks; no showing that other insurers could not have secured similar cost discounts).

73. See text accompanying notes $143-63$ infra.

74. See also notes 63 supra and $186-88$ infra and accompanying text. 
mit lower premiums. They also assist providers of care in pricing their services and can therefore eliminate friction over fees between the provider vis-à-vis the insurer and insured. Also, unlike horizontally established minimum fees of the Goldfarb variety, fee schedules do not require market power to be effective, ${ }^{76}$ nor do they prevent price competition for patients who are not insured by the plan utilizing the negotiated schedule. Further, they need not produce uniform charges, for insurers may agree to pay some doctors more than others. Finally, fee schedules in the insurance context will serve a vital social purpose-controlling runaway health care costs, ${ }^{77}$ not by fiat or government fee schedule, but by putting both buyers and sellers in a competitive market setting.

\section{B. The Rule of Reason and Maximum Price Restraints.}

Insurers will probably want price agreements with providers to take the form of maximum, rather than fixed minimum, fees. A schedule of maximums would establish a range within which the provider's fee for a given procedure could fall, depending on the time and skill involved, the results achieved and the difficulty and complexity of the case. The third party could use utilization and quality checks to determine the appropriate fee. Due to their utility, maximum figures have become common in fee schedules in proposed and operating prepaid legal service plans. $^{78}$

These contractual arrangements could be viewed as vertical combinations between buyers and sellers of services, ${ }^{79}$ however, resulting in antitrust scrutiny. Structurally, they resemble maximum resale price restrictions imposed by sellers of goods upon their distributors, which the Supreme Court has twice in recent history denounced as unlawful under section one. ${ }^{80}$ In Kiefer-Stewart Co. v. Joseph E. Seagram \& Sons, Inc., ${ }^{81}$ the Court struck down a horizontal agreement between two li-

75. See note 186 infra and accompanying text.

76. Goldfarb is discussed in text accompanying notes $42-56$ supra. Because of this distinction there will be no coercion, no tying up of a significant portion of the market, and probably no unreasonable restraint of trade. Cf. United States v. Columbia Pictures Corp., 189 F. Supp. 153, 178-81 (S.D.N.Y. 1960).

77. See also Havighurst, supra note 13, at 474-75.

78. See Meeks $882 \&$ n.95. See text accompanying notes $127,131,141-42$ infra.

79. An unlawful combination or contract in restraint of trade can be found in an agreement negotiated between an individual seller and his individual buyer. See, e.g., Albrecht v. Herald Co., 390 U.S. 145, 149-50 (1968).

80. See also Mandeville Island Farms, Inc. v. American Crystal Sugar Co., 334 U.S. 219 (1948) (beet growers could sue sugar refiners for combining to fix the purchase price of sugar beets).

81. 340 U.S. 211 (1951). 
quor manufacturers that imposed a maximum limit on the prices at which wholesalers could resell their products. Despite evidence that the manufacturers' purpose was to break up a price-fixing conspiracy among the wholesalers which had presumably reduced the manufacturers' gross sales, the Court declared that horizontal maximum resale price maintenance (RPM) agreements, "no less than those to fix minimum prices [by and among competitors, cripple] the freedom of traders and thereby [restrain] their ability to sell in accordance with their own judgment." $" 82$ Kiefer-Stewart did not announce a per se rule in terms, but the enigmatically terse opinion of the Court did seem to apply the language and the reasoning of per se cases, ${ }^{83}$ and the case has been read as holding maximum RPM to be illegal per se. ${ }^{84}$

Subsequently, in Albrecht $v$. The Herald Co. ${ }^{85}$ the Supreme Court held that it was unlawful under section one for a newspaper manufacturer to insist that its retail distributors sell its newspapers at or below a stated maximum price. The majority found, rather unconvincingly, that Kiefer-Stewart controlled the outcome of the case. ${ }^{86} \mathrm{It}$ did not characterize that decision, however, as setting forth a per se rule, but instead, after discussing several ways in which vertical maximum RPM could be economically abusive (none of which were identified as present in the facts of $A l b r e c h t$ ) concluded that the challenged price restraint, "without more," violated the Sherman Act. ${ }^{87}$

Most writers have determined that Kiefer-Stewart and Albrecht should not be read to denounce maximum RPM under the per se rule. ${ }^{88}$ Unlike normal per se cases, these decisions were not the culmi-

82. Id. at 213.

83. The Court said that it intended to "reaffirm" United States v. Socony-Vacuum Oil Co., 310 U.S. 150 (1940) (holding minimum price fixing agreements between competitors to be per se illegal), and quoted some of the language from that decision: "Under the Sherman Act a combination formed for the purpose and with the effect of raising, depressing, fixing, pegging, or stabilizing the price of a commodity in interstate or foreign commerce is illegal per se." 340 U.S. at 213 (quoting Socony-Vacuum, 310 U.S. at 223). The Court offered no explanation why the SoconyVacuum dictum applied to a maximum price agreement in an RPM context, other than that the agreement would restrict a businessman's freedom to sell in accordance with his own judgment. See text accompanying note 82 supra. But that rationale would seem to apply to any commercial contract. Clearly, more analysis was needed to explain why horizontal maximum RPM agreements should not be covered by the rule of reason that controls the validity of most commercial contracts. See Standard Oil Co. v. United States, 221 U.S. 1, $63-67$ (1911).

84. See, e.g., Albrecht v. Herald Co., 390 U.S. 145, 164-65 (1968) (Harlan, J., dissenting); E. GeLlhorN, supra note 65, at 183; J. von KaLINOWSKI, ANTITRUST LAWS AND TRADE REGULATION, 16 Business OrganizATIONS $\S 6.02[3]$ b, at 6-103-05 \& n.70 (1975); 37 U. CiN. L. Rev. 41 , 413-14 (1968).

85. 390 U.S. 145 (1968).

86. Id. at $151-54$.

87. Id. at 153 .

88. As to Kiefer-Stewart, see Bork (Part II), supra note 37, at 464-65; 37 U. CIN. L. Rev., 
nation of a long series of rulings establishing that the challenged practice can rarely, if ever, be justified and that the usual evidentiary inquiry into purpose, power and effect would be wasteful. ${ }^{89}$ Nor did these decisions discuss the possible benefits and detriments to efficiency and competition posed by the restraint under attack, so as to conclude that virtually no defense would be successful, as have most per se cases. $^{90}$ It is plain, moreover, that the results of Kiefer-Stewart and Albrecht can be explained by rule of reason analysis. ${ }^{91}$ Consequently, there is no need to read them as per se holdings condemning maximum

supra note 84, at 413-14. As to Albrecht, see 10 B.C. IND. \& CoM. L. REv. 208, 215-16 (1968); 63 Nw. U.L. REv. 862, 864-65 (1969); 37 U. CiN. L. REV., supra note 84, at 414-16.

89. See J. von KalinowsKI, supra note $84, \S 65.02[1] \mathrm{b}$, at 6-75-79. See also United States v. Socony-Vacuum Oil Co., 310 U.S. 150, 212-24 \& n.59 (1940), discussing numerous prior minimum horizontal price fixing cases and the possible economic benefits and harms of such restraints, concluding that minimum price fixing agreements deserve to be held illegal per se, whatever their purpose and effect. By contrast, Kiefer-Stewart and Albrecht are the only maximum price restraint cases that the Supreme Court has decided, and no other such cases are cited in either opinion.

90. See J. voN KALINowSKI, supra note 84, § 6.02[1]b, at 6-75 \& n.19; see note 89 supra. See Bork (Part II), supra note 37, at 464-65, for a discussion of some of the possible benefits and harms of maximum price fixing.

While horizontal and vertical maximum resale price restraints may be rightly condemned in many instances as unreasonable restraints of trade, there are legitimate defenses that might be discernible in the facts of individual cases. Anticompetitive motives seem to be relatively easy to identify; but where the manufacturers' interests coincide with the consumers', maximum RPM should be permitted, unless the same desirable ends can be attained through less restrictive alternatives, such as suggested retail prices.

91. The Kiefer-Stewart result is perhaps best explained by the very real coercion that the manufacturers were imposing on their wholesalers. Not only did they set maximum resale prices, but they also agreed to minimum prices to the wholesalers which restricted the latter to a narrow and inflexible price range. No competition was realistically possible; the maximum was, in effect, the only price at which wholesalers could sell. Yet, since minimum price agreements were at that time protected from Sherman Act attack under state fair trade laws, competition could be restored only by striking down the maximum RPM agreement. See 37 U. CIN. L. REv., supra note 84, at 413-14. Kiefer-Stewart can also be interpreted as a condemnation of a vertical restraint imposed pursuant to an unjustifiable horizontal combination. See Albrecht v. Herald Co., 390 U.S. 145, 164-65 (1968) (Harlan, J., dissenting); Bork (Part II), supra note 37, at 464. Finally, Kiefer-Stewart may be viewed as condemning a restraint for which there was a less restrictive alternative. Defendants sought to put an end to an unlawful cartel by creating one of their own. A noble goal, but one which they could have achieved through much less questionable means-they might simply have brought suit under section one, alleging that defendants' price fixing had reduced the sales of their products.

Albrecht too is explicable by rule of reason analysis. As in Kiefer-Stewart, the majority indicated that a vertical maximum price restraint could not stand where it arose in connection with an entirely unjustifiable restraint, in this case a territorial allocation system for newspaper distribution. See 63 Nw. U.L. Rev., supra note 88, at 864-65; 37 U. CIN. L. REV., supra note 84, at 414-15. Indeed, Justices Douglas and Harlan thought that the legality of the territorial restraint was the only real issue in Albrecht. 390 U.S. at 154-56 (Douglas, J., concurring); id. at 165-66 (Harlan, J., dissenting). The Herald did not show that it had lawfully granted Albrecht a territorial monopoly; hence it failed to prove that its maximum price restraint was legitimately intended to prevent price gouging. Under these cases, maximum RPM might well be held lawful where it is used to restrain legally acquired market power. 
RPM. ${ }^{92}$

There are compelling reasons not to apply the rule against vertically imposed price restraints in the context of fee controls on medical and hospital services. Insurer-provider cost-control agreements differ from the restraints at issue in Kiefer-Stewart and Albrecht in both facts and policy. First, insurer-initiated controls over providers do not require market power to be effective, even though a horizontal combination in Kiefer-Stewart and the market power of a newspaper in Albrecht made controls effective. Second, insurer price controls over physicians and hospitals do not restrict the resale price of anything. RPM of the Kiefer-Stewart and Albrecht variety "cripples the freedom of traders" to resell to consumers the goods they have purchased from the manufacturers. However, the price fix in insurer-provider contracts occurs at the first purchase because the insurer does not merely act in the interest of the ultimate purchaser-it is the ultimate purchaser. These are purchase and sale agreements with no restraint on alienation. Third, antitrust policy would prefer contractual price controls in the health insurance field over the Kiefer-Stewart and Albrecht restraints because no less restrictive method can achieve the socially favored purpose of cost control, the purportedly primary goal in all three instances. The defendants in Kiefer-Stewart could have fulfilled this purpose without price restrictions by suing their distributors for price fixing under section one of the Sherman Act. The Herald Company could have ended Albrecht's price raising activities simply by eliminating the territorial restrictions which it had itself imposed on its distributors and which shielded him from price competition. In comparison, insurers have no analogous alternative because the ability of health care providers to charge high prices is a lawful result of their natural monopoly power over their patients. ${ }^{93}$

Viewed under rule of reason standards, cost-control fee agreements between single insurers and single providers should escape section one proscription for the above reasons. In terms of power, purpose and effect, maximum fee schedules should present little to lift the eyebrows of the antitrust court, with two caveats. First, price control agree-

92. See also Continental T.V., Inc. v. GTE Sylvania, Inc., 433 U.S. 36 (1977), holding that territorial restrictions in dealer franchise contracts, previously held to be per se illegal in United States v. Arnold, Schwinn \& Co., 388 U.S. 365 (1967), are to be judged by the rule of reason. The Court reinstated the rule of White Motor Co. v. United States, 372 U.S. 253 (1963), that vertical restraints as to customers and territories are not per se illegal. The Sylvania rationale - that per se rules are proper only against practices that are manifestly anticompetitive--should also shatter the seeming "per se" rule of Kiefer-Stewart and Albrecht. See note 91 supra and text accompanying notes 88-91 supra.

93. See text accompanying notes $59-60$ supra. 
ments initiated by an insurer with dominant power in the market would evoke the dangers associated with monopsony pricing, such as coercion and entry-limit pricing, and should probably be forbidden. ${ }^{94}$ Second, if the maximum figures set in each insurer-provider contract tended in practice to become the minimum charges as well, the case law barring vertically imposed minimum prices might be invoked against them; ${ }^{95}$ the better logic, however, would find even contractual minimum prices to be justified under the ancillarity doctrine. ${ }^{96}$

The utility, as well as the limits, of the foregoing analysis of ancillary restraints and maximum fees are aptly demonstrated by the antitrust experience of prepaid drug and legal service plans. The antitrust principles that emerge from those experiences serve well as a guide for the proper structure of any insurer-initiated fee constraint programs for medical care providers. It is perhaps indicative of the medical profession's power and resistance to infringements on doctors' fee-setting prerogatives that experience with fee schedules has been more extensive in these other fields than in medical insurance.

\section{Antitrust Experience with Prepaid Drug and Legal Service Plans.}

1. Prepaid Drug Plans. Prepaid drug subscription plans typically involve contracts between insurers and pharmacists under which the insurer undertakes to pay, as payment in full for drugs furnished to insureds, the cost of the drug to the pharmacist plus a service fee. The service fee may be computed either as a fixed percentage of that cost, as a single sum added uniformly to all prescriptions or as a combination of the two. ${ }^{97}$ Whichever approach is taken to professional pharmaceutical fees, however, it is evident that readily identifiable costs constitute a

94. See notes 71-72 supra and accompanying text.

95. See Dr. Miles Medical Co. v. John D. Park \& Sons Co., 220 U.S. 373 (1911); P. AREEDA, supra note 65, at 500-04. Professor Bork has questioned the rationale of the Dr. Miles case, pointing out that minimum RPM is economically desirable in many instances and should be judged under the rule of reason. Bork (Part II), supra note 37; Bork, $A$ Reply to Professors Gould and Yamey, 76 YALE L.J. 731 (1967); see also E. GELLhoRN, supra note 65, at 254-60. Arguably, Dr. Miles should have no bearing in the insurance context in any event because health care fee agreements do not restrain the resale of any goods or services. Compare the discussion of KieferStewart and Albrecht in the text accompanying note 93 supra.

96. This logic has been followed in antitrust experience with prepaid drug plans. See notes 57-77 supra and accompanying text.

97. See Myers, 10 Am. Pharmaceutical A.J. 628, 632, 636, 639 (1968); Oppenheim, Antitrust Policy and Third-Party Prepaid Prescription Drug Plans, 40 Geo. WAsh. L. Rev. 244, 246 (1971). The uniform professional fee approach is increasingly prevalent in recently designed prepaid drug plans, but the "variable fee" approach is arguably fairest and most advantageous to small pharmacists since it can take into account the differences in operating costs of different drug retailers.

Consumers may, under any of these plans, purchase drugs from nonparticipating druggists, 
larger proportion of the total charge in the pharmaceutical retail industry than in the medical care industry and that fewer variables complicate the service fee computation. This is probably one reason that insurers finally did begin employing contractually fixed prices in prepaid prescription plans but not in plans covering medical and hospital services. 98

In a 1969 address to a convention of retail pharmacists, a Department of Justice spokesman set forth the Antitrust Division's policies on fee provisions in prepaid drug plans. It is a per se criminal violation of the antitrust law's prohibition of price fixing for professional pharmacists collectively to agree upon service fees or to suggest prices to sponsors of prepaid plans. Pharmacists may not lawfully combine to bargain collectively for prices for dispensing drugs. Third-party plans may lawfully set uniform drug service fees, but only if the third party unilaterally adopts the fee and if pharmacists decide individually whether to participate in the plan and to accept its prices as reasonable. Although an insurance firm may discuss suggested prices with individual pharmacists, it will open itself to prosecution for participation in a price fixing scheme if it solicits suggested prices from groups of pharmacists or solicits agreements from such groups of pharmacists to discover an acceptable price. ${ }^{99}$ Subsequently, another Antitrust Division spokesman clarified the latter point, indicating that "the fact that druggists know that they are receiving [and accepting] offers identical to those made by the carrier to competing druggists does not, in and of itself, result in an agreement [among druggists] in violation of the antitrust laws."100

Implicitly, these guidelines recognize the desirability of insurerimposed controls on drug costs, despite their possible effect of uniform prices. The guidelines stress that the antitrust objection to fee fixing under prepaid plans centers upon price agreements among the recipients of the fees-the providers of services-rather than upon price agreements between individual providers and insurers. When the thirdparty payor is involved, the fee limitation may appropriately be viewed

but they are penalized for doing so since they will only be reimbursed for a portion (usually $75 \%$ ) of the amount charged.

98. Another reason may have been the fear of concerted opposition by organized medicine.

99. Address by Lewis Bernstein, Chief of the Special Litigation Section of the Antitrust Division of the United States Department of Justice, before the Annual Convention of the National Association of Retail Druggists, in Las Vegas, Nevada, Oct. 15, 1969, reprinted as Antitrust Aspects of Prepaid Prescription Plans (mimeo), cited in part and quoted in part in Oppenheim, supra note 97 , at $260-62$.

100. Hearings on H.R. 5 \& 19 Before the Subcomm. on Environmental Problems Affecting Small Business of the House Select Comm. on Small Business, 92d Cong., 1st Sess. 231 (1971). See Theatre Enterprises, Inc. v. Paramount Film Distrib. Corp., 346 U.S. 537, 540-41 (1954). 
as a tolerable ancillary restraint, reasonably necessary to the execution of a financially sound insurance plan, because it enables the insurer to make accurate predictions of payments and to compensate for the insured's lack of cost-consciousness in purchasing.

Despite this encouragement from a principal government antitrust watchdog, ${ }^{101}$ early prepaid pharmaceutical plans received a mixed reception. Michigan's Attorney General in 1969 advised Blue Shield and Blue Cross that a proposed drug plan which would pay pharmacists their costs plus a fixed fee set by the Blues might constitute illegal price fixing under the Sherman Act and could also violate Michigan's antitrust law. ${ }^{102}$ The following year, in Blue Cross v. Virginia, ${ }^{103}$ the Supreme Court of Virginia struck down a similar fixed fee Blue Cross prepaid drug plan on the ground that it represented a conspiracy to fix prices and, therefore, was banned by both federal and state antitrust statutes. ${ }^{104}$ Although the Antitrust Division had favorably reviewed a similar plan, ${ }^{105}$ the court's ruling seems consistent with the Division's guidelines, in that Blue Cross had sought and received the support of the state pharmaceutical association on the principle of fixed fees and on the amount of the fee. ${ }^{106}$ The Virginia court also thought it significant that the state's insurance commission had refused to approve the plan on the ground that it constituted a conspiracy to fix prices. ${ }^{107}$ In contrast, the Supreme Court of Illinois approved a somewhat similar prepaid drug plan on the ground that it was exempted from federal and state antitrust prosecution by special state statutory exemptions. ${ }^{108}$

101. The FTC has shown little interest in monitoring prepaid drug plans. It recognizes that complex antitrust and consumer welfare issues must be balanced in this area, but, pending a factual investigation of its own, appears to be willing to follow the Justice Department's thinking. Hearings on Competition, pt.2, at 301-03.

102. Opinion of the Attorney General of Michigan, 1969 Trade Cases 86,917.

103. 211 Va. 180,176 S.E.2d 439 (1970).

104. Id. at 189-92, 176 S.E.2d at $443-46$. The court appreciated the desirable purposes of the plan, $i d$ at $184,188,191,176$ S.E.2d at $441,444,446$, but found that its effect had been to raise and stabilize prices, $i d$. at $184,188,176$ S.E.2d at 441,444 . The decision is favorably reviewed in Comment, $A$ "Fix" at the Local Drug Siore-Blue Cross Runs Afoul of the Sherman Act, 57 VA. L. Rev. 315 (1971). However, Professor Oppenheim vigorously criticized its rationale in Oppenheim, supra note 97 , at $246-66$.

105. 211 Va. at $191-92,176$ S.E.2d at 446 . As the court pointed out, the Antitrust Division's business review letter dealt with plans in California and Kansas and may not have considered all of the facts present in the Virginia case.

106. Id. at 182-83, 187, 188, 176 S.E.2d at 440-41, 443, 444; see note 99 supra and accompanying text.

107. The Bureau of Insurance of the State Corporation Commission initially approved the plan, 211 Va. at 183, 176 S.E.2d at 441, but later condemned it as violative of Virginia and federal antitrust law. Id. at 181, 184, 192, 176 S.E.2d at $440,442,446$.

108. B \& L Pharmacy, Inc. v. Metropolitan Life Ins. Co., 46 Ill. 2d 1, 262 N.E.2d 462 (1970). The case is unfavorably reviewed at 65 Nw. U.L. REv. 940 (1971) on the basis of its interpretation 
Critics of the Blue Cross case charged that it would be but a short step from the Virginia court's per se condemnation of the uniform fee to an antitrust attack upon any formula related to the determination of a professional fee on the ground that the formuladetermined fee inevitably becomes an agreed upon fee between the third-party carrier and the participating pharmacists. ${ }^{109}$

Some pharmaceutical associations, industry representatives and insurance groups pressed for an antitrust exemption to enable pharmacy groups to negotiate fees with insurers. ${ }^{110}$ Alternatively, one pharmaceutical spokesman proposed that rigid antitrust enforcement be tempered to permit such negotiations. ${ }^{111}$ Finally, Professor Oppenheim, on behalf of the pharmaceutical industry, took the surprising position that pharmacists could form a foundation to negotiate price contracts on their behalf without violating the Sherman Act since such a foundation could be viewed as reasonably ancillary to the main lawful purpose of enabling small pharmacists to compete with other sources of prepaid pharmaceutical services (such as HMOs and other "cooperative prepaid health care arrangements") and because of other public interest features (such as review of quality and appropriateness of services rendered). ${ }^{112}$

The Justice Department has stood firm against these proposals, but subsequent developments have suggested that competitive prepaid drug plans can thrive within the limits set in Blue Cross. In 1973, the Antitrust Division reaffirmed the principles of its earlier guidelines and explained that groups of pharmacists may meet with plan sponsors to establish uniform reimbursement forms and methods and to otherwise reduce the administrative burdens of such programs. The Division reiterated, however, that it would consider it illegal for pharmacists to agree to prices charged third parties and to agree to refuse to deal with

of state law. Cf. Cantor v. Detroit Edison Co., 428 U.S. 579, 595-98 (1976) (exemption of business from Sherman Act scrutiny by state regulation will be found only where the exemption is "necessary" to state policy).

109. Oppenheim, supra note 97, at 251. Professor Oppenheim simply missed the point. It is one thing when a group of professionals, acting in their aggregate self-interest, agree to a uniform price; it is quite another when an insurer, acting in its contrary self-interest, negotiates a single price with each of them separately.

110. See Hearings, supra note 100, at 10-15, 306-07, 314; Oppenheim, supra note 97, at 26364; [1972] ANTITRUST \& TRADE REG. REP. (BNA) No. 593, at A-3 \& A-4; [1971] ANTITRUST \& TRADE REg. REP. (BNA) No. 521, at A-19 \& A-20.

111. See Hearings, supra note 100, at 11-12; [1971] ANTITRUST \& TRADE REg. REP. (BNA) No. 521, at A-19 \& A-20.

112. Oppenheim, supra note 97, at 264-66; [1972] ANTITRUST \& TRADE REg. REP. (BNA) No. 593, at A-3 \& A-4. Aside from the ancillarity argument, Professor Oppenheim does not satisfactorily explain why the activities of such foundations would not constitute price fixing or group boycotts. Nor does he explain why small pharmacists could not compete in a more effective and less restrictive manner by subscribing to insurer-designed price proposals. 
any insurer except on terms set by pharmacists. ${ }^{113}$ True to its promise, the Division has twice approved associations of independent pharmacists where no price agreement element was contemplated, ${ }^{114}$ but it has refused to approve prepaid service plans operated by pharmacists who planned to set professional fees. ${ }^{115}$ At least a half-dozen cost-plus, third party-designed prepaid pharmaceutical plans are currently in operation; ${ }^{116}$ until very recently, none had undergone antitrust challenge.

In Royal Drug Co. v. Group Life \& Health Insurance Co., ${ }^{117}$ the Fifth Circuit Court of Appeals found a Blue Shield drug plan illegal under the Sherman Act. As in the Blue Cross case, the defendant (Blue Shield) negotiated a uniform service fee with participating druggists statewide. The plaintiff pharmacists claimed that the price set by Blue Shield was predatorily low-so low that it made the business of pharmacy unprofitable for small independent pharmacists-and that Blue Shield was able to coerce participation in the plan by virtue of its market power. ${ }^{18}$ The court agreed with the plaintiff' contentions and found that Blue Shield's practices could not be excused under the McCarran-Ferguson Act's "business of insurance" exemption. The case

113. [1973] ANTITRUSt \& TRADE Reg. Rep. (BNA) No. 619, at A-7. It is open to question whether the Antitrust Division's concession on "administrative burdens" opened too large a loophole. A recent development in health insurance demonstrates how easily collective bargaining between provider groups and insurers over "administrative burdens" can become collective bargaining for control of a health insurance plan. In that instance, a consortium of medical societies in the Detroit area all but gutted a proposed Blue Cross-Blue Shield second opinion requirement in elective surgery cases by overloading it with preconditions, including a two-year retrospective study of the value of second opinion requirements before the plan became operational, and demanding that medical society representatives participate in the management of the plan. See MDs Winning "Second Opinion" Fight, Am. Med. News, Apr. 18, 1977, at 1. Possibly, the Antitrust Division's stance can be justified on the ground that administrative problems in drug plans are much less complex than the administrative problems that may arise in medical care plans and are therefore less likely to interfere with the cost control purpose. But competitive strategies can focus on administrative efficiencies, too; it seems anomalous that the Division did not require that they be given a chance to do so.

114. See [1975] ANTITRUST \& Trade Reg. ReP. (BNA) No. 744, at A-14 (approving formation of association of independent pharmacies in southern California to enable members to buy drugs and other health-related items at prices normally available only to buyers of large quantities; members are not to agree on resale prices and association will not suggest or exert pressure as to resale prices); [1975] ANTITRUST \& TRADE REG. REP. (BNA) No. 740, at A-9 (approving organization of Missouri Foundation for Pharmaceutical Care, a nonprofit foundation managed by pharmacists, health care providers and consumers (but not controlled by pharmacists) for the purpose of operating a prepaid pharmaceutical service plan under contract with insurer, employer, union and government groups; participating pharmacists are to charge their own usual, customary and reasonable fees).

115. See [1975] ANTitrust \& Trade Reg. Rep. (BNA) No. 787, at A-14.

116. See Council on Wage and Price Stability, supra note 10, at 40298, 40305-07, 40317-18.

117. 556 F.2d 1375 (5th Cir. 1977), cert. granted, 98 S.Ct. 1448 (1978).

118. See id.at 1378-80 (reciting plaintiff' allegations and holding that the McCarran-Ferguson Act does not immunize Blue Shield from the Sherman Act). 
appears to present a situation of a monopsonistic insurer fixing the price at which it purchases services. In such a case, the court could properly find the price fix to be unlawful under the rule of reason.

Antitrust experience with prepaid pharmaceutical plans, although limited, bolsters the belief that the basic policy concern in insurer-provider cost-control schemes utilizing fee schedules is not with the vertical price-determining aspect of the plan but with the danger of horizontal price agreements among providers. Problems for third parties arise not merely when the third party uses its aggregate buying power to negotiate a good price with providers, but also when, as in Blue Cross, it negotiates with provider groups or invites price talks with or among such groups or when, as in Royal Drug, the insurer possesses monopsony power and wields it coercively to exploit suppliers of services. Some authority would question the legality of any plan that promotes price uniformity among its participants, but the Justice Department eschews that approach, at least where pharmacists are free to participate in numerous plans, thereby promoting interplan competition. ${ }^{119}$ Given the even more noticeable differences in skill and efficiency that presumably exist among physicians than among pharmacists, ${ }^{120}$ one would expect insurers not to propose uniform prices to all providers participating in a prepaid health plan but rather that there would be intraplan, as well as interplan, price competition in the medical services market. Hence, antitrust risks seem to be of lower degree in prepaid medical insurance than in prepaid drug insurance and should be all the more readily undertaken.

2. Prepaid Legal Service Plans. The concept of insurance for professional services is much newer to the legal profession than it is to the medical profession. Prepaid medical plans in this country have blossomed since the 1930s and can be traced to the nineteenth century, ${ }^{121}$ but prepaid legal plans were still in the planning stages in the

119. Compare note 102 supra and accompanying text with notes $99-100$ \& 113 supra and accompanying text.

120. This assertion does not intend to demean professional pharmacists and their valuable work, but only refers to the fact that physicians' services are broader in range and variety, and, accordingly, in the skill and efficiency with which they are performed, than pharmacists' services.

121. Although the third party medical payment system stems ultimately from the mutual benefit funds used in medieval guilds, H. Somers \& A. Somers, supra note 9, at 225 , the third party reimbursement concept in this country can be traced back only to the 1800 s. However, the mushroom growth of the third party system has been more recent. Health insurance did not firmly take root until the great depression of the 1930s when physicians and hospitals began to require that their fees be paid. See S. Law, supra note 9, at 6-11; Physician Control of Blue Shield Plans is Subject of FTC Antitrust Investigation, Wall St. J., Feb. 27, 1976, at 6, col. 3. Between 1940 and 1972 , fiscal intermediaries increased their population coverage from 12 million to 182 million persons, embracing now fully $90 \%$ of the American people. Hanson, The Private Insurance Indus. 
late $1960 \mathrm{~s}^{122}$ and operate today in only a few localities. ${ }^{123}$ The organized legal profession, however, has come to back the insurance concept as a means of ethically financing legal services and of extending them to groups that previously had little access to them, particularly the middle class, ${ }^{124}$ and it seems safe to assume that legal insurance is here to stay. Since the Goldfarb case specifically applied antitrust principles to the legal profession, ${ }^{125}$ the designers of and potential participants in new prepaid legal insurance plans have been especially conscious of the problems of determining legal service fees without incurring antitrust attack.

No antitrust suit has yet challenged the payment mechanism or any other aspect of any prepaid legal service plan. However, the American Bar Association has issued antitrust guidelines regarding prepaid plan pricing mechanisms that closely track the foregoing discussion of price manipulations in prepaid medical and pharmaceutical service plans. ${ }^{126}$ The $\mathrm{ABA}$ envisions a plan proposing maximum price schedules which would bind participating attorneys as a form of fee control. ${ }^{127}$ It concludes that no antitrust problem would arise if the

Iry and State Insurance Regulatory Activities as Alternatives to Federally Enacted Comprehensive National Health Insurance Legislation, 6 U. ToL. L. REV. 677, 690-91 (1975) (statistics include coverage by HMOs and FMCs). See also KRIZAY \& WILsON 8-10; H. SOMERS \& A. SoMERs, supra note 9, at 254-60.

122. See Stolz, Insurance for Legal Services: A Preliminary Study of Feasibility, 35 U. CHI. L. REV. 417 (1968).

123. For recent discussion of planned and operative prepaid legal services programs, see, e.g., Boeggeman, Prepaid Legal Services-Some New Developments, 25 FED. INS. CoUNSEL Q. 327 (1975); Meeks 859-65; Pfennigstorf \& Kimball, Regulation of Legal Service Plans, 1977 AM. B. Foundation ResearCH J. 359; Young, Group Legal Services and Canon II, 34 MD. L. REv. 54l, 551-65 (1974).

124. See Grainger, Prepaid Legal Services-An Update, 26 FED. Ins. Counsel Q. 230, 23334 (1976); Washington Note 1012 n.6, 1013-25.

125. See notes 42-56 supra and accompanying text. See also American Bar Association and Justice Department Explain Positions on Minimum Fee Schedules to Senate Subcommittee, 59 A.B.A.J. 1296, 1298-1300 (1973).

126. See, e.g., ABA Speclal Committee on Prepaid legal Services, Compilation of Reference Materials on Prepaid Legal Services, "Antitrust" at i (1973); Boeggeman, supra note 123, at 335; Grainger, supra note 124, at 234; Meeks; Washington Note 1025-70. Some prepaid legal insurance plans and their proponents have assumed that plans could be marketable and actuarially sound without imposing any price restraints on providers of legal services. See, e.g., Politz, The Longsought Answer?, 7 TrLal 29, 32 (Mar./Apr. 1971); Sorenson, Trends in Prepaid Legal Insurance, 1973 INS. L.J. 209, 213; Young, supra note 123, at 556, 557, 559. But it was also recognized that "[t]here is no easy answer" to the problem of possible misallocation of expensive resources posed by the difficulties of defining "legal services" without fee schedules and preventing the over-utilization of lawyers which insurance encourages. Stolz, supra note 122, at 429-36; see Meeks 876 \& n.73. And it is said that the failure of prepaid legal plans to state what portion of a lawyer's fee will be paid has hindered their acceptance by the public. See Young, supra note 123, at $558 \mathrm{n} .80$ and authorities cited therein.

127. Compare notes 78-96 supra and accompanying text. 
schedule is agreed to by lawyers or law firms acting alone or if the agreeing lawyers are employees of the plan. ${ }^{128}$ Similarly, no problem occurs where "the fee schedule is set by an insurance company, by a consumer group, or by any other group other than those who provide service and receive payment therefor," even though such a substantial number of lawyers agree to the plan that the maximum fee schedule makes prices more uniform in the legal services market. ${ }^{129}$ However, where the plan designing such a schedule is controlled by lawyers or representatives of the organized bar-and "[m]ost plans contemplated by the various state and local bar associations are now in this form"- the schedule constitutes price fixing. ${ }^{130}$

The Department of Justice has lent support to these guidelines in its repeated refusals to approve the establishment of California Lawyers Service (CLS), a nonprofit open-panel prepaid legal services foundation sponsored by the State Bar of California. Under the CLS plan, participating lawyers would provide services throughout the state at maximum fee levels to be established by CLS. ${ }^{131}$ In discussing its reasons for denying favorable review to the plan, which it plainly considers desirable in principle, ${ }^{132}$ the Antitrust Division indicated that a proposal to retain control over CLS entirely among lawyers for an initial three-year transition period "would create serious competitive risks." ${ }^{133}$ The Division did not state that possible price fixing was its sole or chief objection to professional control of CLS, but it did declare that no price schedule would be sanctioned without further investigation of its compilation and final form. ${ }^{134}$

Two other features of the Antitrust Division's refusal to approve the CLS plan warrant mention. First, the CLS fee schedule proposal was to be based upon a relative value schedule for lawyers' services that would be designed by an independent accounting firm; no antitrust clearance could be given "until after the survey has been completed and the Department has investigated the manner in which it has been

128. See ABA Special Committee on Prepaid Legal Services, supra note 126, at i.

129. Id. See Meeks 875 \& n.66.

130. ABA Special Committee on Prepaid Legal Services, supra note 126, at i. See Meeks 875-82. See also Grainger, supra note 124, at 234; Washington Note 1037.

131. See [1975] Antitrust \& Trade Reg. Rep. (BNA) No. 702, at A-12.

132. See id; Letter from Thomas E. Kauper to Peter F. Sloss (Aug. 5, 1974), reprinted in Boeggeman, supra note 123, at 337-40.

133. Letter, supra note 132, at 338. See also [1977] ANTITRUST \& TRADE REG. REP. (BNA) No. 805, at A-22 (in a business review letter of Feb. 4, 1977, the Division denied approval of a plan sponsored by the New York County Trial Lawyers' Association substantially similar to the CLS proposal, whereby the Association was to set the fees for the first year of operation only) (discussed at notes 141-42 infra and accompanying text).

134. Letter, supra note 132, at 340. 
conducted and examined the results."135 Presumably, the Division was concerned primarily with the possibility of lawyer-controlled CLS manipulation of the relative value schedule, but no indication was given of the antitrust status of such a schedule if CLS were not dominated by lawyers. At least one other antitrust writer has, however, concluded that use of a relative value study in the latter circumstances would be lawful. ${ }^{136}$

Second, the Antitrust Division opposed the CLS proposal because its role, in light of other state bar restrictions on prepaid legal service plans, might be to restrain interplan competition. Because it was "primarily concerned" with the plan's impact on "the development and preservation of competitive alternatives for the delivery of legal services to the public," the Division could not approve an open-panel prepaid plan that would enjoy special advertising and solicitation advantages over closed-panel prepaid plans to such an extent that the latter might be squelched as a competitive force. ${ }^{137}$ This concern for closed-panel plans is important. Open-panel plans resemble traditional medical care financing structures-the consumer chooses the lawyer he wants and the lawyer bills his usual fee. ${ }^{138}$ Closed-panel plans are analogous to what health care financing would look like under a system of fee-restrictive contracts-the consumer may procure services under the plan only (or primarily) from participating attorneys whose charges are dictated by a schedule. ${ }^{139}$ Numerous commentators have supported the Justice Department's conclusion that closed-panel plans are desirable competitive alternatives to open-panel arrangements and that organized professional resistance to them constitutes an unlawful restraint of trade. ${ }^{140}$ This backing of the closed-panel concept should be viewed as a green light to health insurers.

135. Id.

136. See Washington Note $1037-38$ \& 1069 .

137. See Letter, supra note 132, at 338-39. Kauper further objected to the California State Bar's prepaid plan restrictions in that they would unreasonably limit the number of open panel plans that could compete with CLS. Id. 339-40.

138. See Washington Note 1013 \& n.7.

139. See id. at $1013 \&$ n.8.

140. See Boeggeman, supra note 123, at 335-36; Grainger, supra note 124, at 234; Washington Note 1028-36. See also id. at 1024 (closed panel plans generally cost consumers less than open panel plans). The primary theory advanced by these authors is that bar association discrimination against closed panel plans constitutes an illegal group boycott. The United States Supreme Court has upheld the validity of several closed panel legal plans. See United Transp. Union v. Michigan State Bar, 401 U.S. 576 (1970); United Mine Workers v. Illinois State Bar Ass'n, 389 U.S. 217 (1967); Brotherhood of R.R. Trainmen v. Virginia State Bar, 377 U.S. 1 (1964); NAACP v. Button, 371 U.S. 415 (1963). For discussion of various bar association approaches to restraining competition among closed and open panel plans, see Washington Note 1013-23. But see Grainger, supra note 124, at 234 (positing that closed panel plans themselves might be viewed as illegal 
Recently, the Antitrust Division has clarified its position on the extent to which lawyers may participate in controlling the fee schedule for a prepaid service plan. The New York County Lawyers' Association proposed a plan whereby the association would set maximum fees for participating lawyers during the first year of operation, and thereafter the fee schedule would be supervised by a subscriber-dominated managing committee. Initially, the Antitrust Division opposed the plan because the association would stabilize fees without consumer input during the pilot year. ${ }^{141}$ However, when the plan was subsequently revised to permit the subscriber-dominated committee to alter the fee schedule even during the pilot year, the Division gave its blessing. ${ }^{142}$ This series of events shows that antitrust policy objects not merely to fixed minimum, but also to maximum prices when they are established by concerned professionals, and even when the period of the fix is relatively short. However, where those with economic interests adverse to the profession's are in a position to control the schedule, antitrust objections are obviated.

\section{Separating Fee Schedules from Provider Control: The Crucial Limitation}

The foregoing discussion of ancillary restraints, maximum fees and prepaid drug and legal service plans allows some definite lines to be drawn on the permissible scope of fee schedule arrangements in the medical profession. This section of the Article will delineate those guiding principles, and then argue that two existing forms of fee schedule arrangements-fee schedules set by foundations for medical care (FMCs) and the Blue plans' UCRF system-appear to violate them.

The governing rule that emerges from the prepaid drug and legal service plans is that the antitrust laws basically support such plans ex-

group boycotts). For discussion of constitutional theories under which restrictions on prepaid insurance plans may be attacked, see Washington Note 1066-67 n.303.

141. See [1977] ANtitrust \& Trade Reg. Rep. (BNA) No. 805, at A-22.

142. See [1977] ANTITRust \& TRAde REG. ReP. (BNA) No. 809, at A-11. One must question how any bar association promulgated fee schedule can escape antitrust proscription. See notes 189-212 infra and accompanying text for discussion of why medical association fee schedules should be held impermissible. There is danger that such schedules will set floor prices at noncompetitive levels that may infect the entire industry. But maximum prices, as opposed to minimum prices, present a lesser threat to competition. See Meeks 884-85; see notes 78-96 supra and accompanying text. It could also be argued that prepaid legal plans, unlike prepaid medical plans, are so new and lacking in actuarial fee data that there was no alternative to minimal bar association participation at the outset and that, therefore, the involvement present here could be justified under the rule of reason. Under this analysis, the initial fee schedule would be excused as the kind of "purely advisable fee schedule" referred to in the Goldfarb case, see notes 54-56 supra and accompanying text. 
cept to the extent that they camouflage or embody horizontal agreements by competing providers of services. Physicians may not agree as a group on an acceptable fee arrangement or suggest that arrangement to an insurer. Physicians may not combine and collectively bargain for favorable fees. ${ }^{143} \mathrm{~A}$ fee schedule would be illegal if it received the imprimatur of a medical association or if a medical association served as an "advisor" to an insurer in its compilation. Fee schedules, to pass muster under the antitrust laws, must be unilaterally initiated by insurers and offered to individual providers for their acceptance or rejection.

The line between legal and illegal fee arrangements may often be extremely fine. It would not be illegal, for example, for individual physicians to be aware of the fact that other physicians are receiving substantially similar fee arrangement offers. It would, however, violate the antitrust laws if physicians made their acceptance or rejection decisions in concert or conditioned their acceptance upon the agreement of others. It would also violate conventional antitrust analysis if doctors made their decisions in a consciously parallel fashion, that is, if an exchange of pricing information through fee schedules amounted to a tacit invitation to follow a concerted pricing course and the invitation were uniformly acted upon.

143. Health care providers have pushed the notion that they may permissibly "unionize" to enter into "collective bargaining" with insurance carriers. See Craver, The Application of Labor and Antitrust Laws to Physician Unions: The Need for a Re-Evaluation of Traditional Concepts in a Radically Changing Field, 27 HAsrings L.J. 55, 87-92, 95-97 (1975); MDs May Quit Blue Shield Plan, Am. Med. News, Dec. 13, 1976, at 21 (a doctors' guild sent notices to Arizona's 2800 physicians asking whether they wanted the guild to be their statewide bargaining agent in Blue Shield reimbursement rate discussions). Through such collective action providers hope to avoid victimization at the hands of so-called insurer "Goliaths." See Alper, Why I Joined A Union, PrISM, May 1974, at 26; Craver, supra, at 59 and authorities cited at 59 n.23; cf. Oppenheim, supra note 62, at 252. But the FTC does not share their enthusiasm that federal labor legislation could exempt doctor groups from the Sherman Act, see [1977] ANTITRUST \& TRADE REG. REP. (BNA) No. 803, at A-19, A-21. Other commentators have convincingly argued that it would be inappropriate to construe physician "unions" as labor groups because most health care providers are independent contractors, not employees, see Glantz, A Reply to Professor Craver: Physicians in Private Practice Already Have Enough Power, 27 Hastings L.J. 315, 316-17 (1975); Comment, Private Physician Unions: Federal Antitrust and Labor Law Implications, 20 U.C.L.A. L. REv. 983, 1001-06 (1973), and because the monopoly power already wielded by providers, see note 60 supra and accompanying text, even now affords them individual bargaining power "far beyond anything a normal union could desire," Glantz, supra, at 316; see id. at 330; cf. Craver, supra at 75 (individual action by physicians would probably suffice to encourage insurers to reconsider any "opprobrious policies"). The antitrust prohibition would not, of course, apply to physician employees of health care plans such as HMOs; those groups have abandoned the fee-for-service monopoly practice and already enjoy the benefits of federal labor law. See Craver, supra at 91-92; Glantz, supra at 317. Nor would it prevent the formation of HCAs, where the organizing insurer would negotiate a fee schedule independently with each participating provider. See note 68 supra and accompanying text. 
Obviously, policing fee schedules so as to prevent them from crossing the line from desirable cost control to impermissible horizontal combinations can be difficult. Nevertheless, an acceptable bright line guide can be fashioned. Fee schedules that are developed with any involvement by a medical association of any kind should be condemned per se. Fee schedules that are initiated as the independent effort of insurers, however, and are negotiated with doctors who make their decisions individually, should be encouraged. This kind of arrangement should be approved unless there is affirmative proof that it has been abused-that it is a sham that hides an agreement among doctors, perpetrated either by a deliberate combination to fix prices or through the more subtle pressures of a medical association. Unfortunately, the fee schedule efforts that have been the most prevalent in the medical profession to date fall on the impermissible side of this antitrust analysis.

Perhaps the most blatant examples of concerted provider involvement in fee setting arrangements are the FMCs. ${ }^{144}$ FMCs are individual practice associations ${ }^{145}$ that provide prepaid health care but are sponsored or managed by state or county medical societies rather than, as in the case of group practice prepayment HMOs or insurance companies, by lay groups. ${ }^{146}$ FMC plans are structurally similar to HMOs and differ from conventional health insurers in that the same organization acts as both insurer and provider of care. Theoretically, this structure stimulates cost savings by creating financial incentives for participating physicians to police each other's performance to seek efficiencies in treating patients. ${ }^{147}$ In addition to utilization review, ${ }^{148}$ FMCs set limits on the fees paid for each type of service. ${ }^{149}$ Although the maximum fees may be set by means other than the UCRF approach, the parallel to the practice of Blue Shield plans is close. Indeed, FMCs have been described as second-generation Blue Shield plans en-

144. See generally K. Bauer, Containing Costs of Health Services Through Incentive Reimbursement 211 (1973); H. Somers \& A. Somers, supra note 9, at 422-23; Auger \& Goldberg, Prepaid Health Plans and Moral Hazard, 22 PuB. PoL'y 353, 358-63 (1974); Egdahl, Foundations for Medical Care, 288 NEw ENGLAND J. MED. 491 (1973); Sasaly \& Hopkins, $A$ Medical Society-Sponsored Comprehensive Medical Care Plan, 5 MED. CARE 234 (1967).

145. See sections $1302 \& 1311$ (a) of the HMO Act of 1973, 42 U.S.C. $\$ \$ 300-1(5) \& 300$ e10(a) (Supp. V 1975). FMCs are a variety of what was formerly known as prepaid group practice, a form of health insurance in which contracting providers offer a complete line of medical services to the public on the basis of a prepaid annual capitation fee. In 1971, these plans covered about five percent of Americans. KRIZAY \& WILSON 125-41.

146. FMCs also differ from HMOs and commercial insurance in that they provide intensive peer review of fees and utilization.

147. See KRIZAY \& WILSON 125-41.

148. See Havighurst, HMO's 769; Note, The Role of Prepaid Group Practice in Relieving the Medical Care Crisis, 84 HaRv. L. Rev. 887, 919-21 (1971).

149. See KRIZAY \& WiLson 140; Egdahl, supra note 144. 
gaging in somewhat more aggressive cost containment than traditional service plans. ${ }^{150}$ Some FMCs have not in fact accepted financial risks but have instead been enlisted by health insurers to perform PSRO-like cost containment services that the insurers have not been willing to supply themselves. ${ }^{151}$

One should note the crucial distinction between the efforts of FMCs, which are run by organized medicine, and the cost-containment measures suggested in this Article. Because of the medical society sponsorship of FMCs, their maximum price control takes on a horizontal aspect not present in insurer-initiated plans. The price-determining activities of the foundations go far beyond the limits indicated by the data dissemination cases. ${ }^{152}$ Structurally, FMCs closely resemble the proposed bar-sponsored prepaid legal insurance plans to which the Justice Department has objected on Sherman Act grounds. ${ }^{153}$ It should come as no surprise then that FMC-type provider price-control activities, especially some of the Blue plans, are being attacked as anticompetitive. ${ }^{154}$ Professor Havighurst has forcefully argued that the very purpose of FMCs is to set an entry-discouraging price that will preclude other forms of third party competition and thus that a per se rule would be appropriate to condemn them. ${ }^{155}$ Indeed, an antitrust rule against horizontally fixing maximum, as opposed to minimum, prices makes sense only because of the probability that entry-limiting pricing is involved..$^{156}$

The success of the foundations, ${ }^{157}$ like Blue Shield plans before them, ${ }^{158}$ in perpetuating fee-for-service medicine and precluding development of alternative delivery and financing systems suggests that no less restrictive alternative to insurer-imposed fee limits is available to achieve meaningful cost restraints in the health care industry. Even at their best, FMCs raise neither competitive nor countervailing forces to break down or offset the monopoly power of contracting providers;

150. Havighurst, Speculations on the Market's Future in Health Care, in AMERICAN ENTERprise Institute, Regulating Health Facilities Construction 249, 257-62 (C. Havighurst ed. 1974).

151. Id.

152. See notes 198-213 infra and accompanying text.

153. See notes 131-36 \& 141-42 supra and accompanying text.

154. See Havighurst, HMO's 768-70. No antitrust actions have yet been brought against FMCs as of the time of this writing.

155. Id. at 769-77; cf. Egdahl, supra note 144, at 496 (FMC operations could destroy the viability of third party insurers as independent intermediaries in the health care delivery system). But see Comment, supra note 143, at 1009-10.

156. See P. AREEDA, supra note 65 , at 317.

157. See Egdahl, supra note 144.

158. See United States v. Oregon State Medical Soc'y, 343 U.S. 326 (1952). 
rather, they preserve and perpetuate that power by curbing only its worst excesses.

A second example of a fee-setting arrangement that ought not to be permitted to stand under the antitrust laws is the UCRF reimbursement system that has been utilized by the Blue service plans. The problems of the UCRF system have already been discussed; ; 159 they revolve around the tendency of maximum UCRF limits to become minimum price floors for the entire medical community. The premise of the UCRF is that physicians are subject to competitive pressure in setting their prices and that reference to "usual" and "customary" fees constitutes reference to objective, market-determined prices. But, as service plans and insurers have covered more and more physicians' services, that premise has weakened and seems now to have largely disappeared. To a large degree, physicians' prices are now "administered;" lower fees do not expand a physician's business, and higher fees not only cost the physician few customers but, under the UCRF regime, are their own excuse for being.

Although in theory physicians participating in service plans using the UCRF approach to fee control are not given information on the maximum charge that will be paid, in practice the charge is probably not difficult to ascertain. Physicians may exchange such information or they may simply derive it through trial and error-charging high fees and reducing them in increments until they are finally paid by the plan. Secrecy has not prevented the prevailing maximum from quickly becoming first a minimum and then a plateau from which to launch another fee increase.

When the UCRF system's price-raising possibilities are coupled with the historic ties that Blue Shield plans have had with the medical profession and the involvement that medical groups have had in the establishment and implementation of maximum fees, the UCRF system presents a serious risk that its net effect is to raise fees rather than to lower them. ${ }^{160}$ But, whether or not this risk has materialized in fact (a matter that would probably be hard to prove in an antitrust case),

159. See notes 18-26 supra and accompanying text.

160. See, e.g., Ohio v. Ohio Medical Indem., Inc., Civil No. C-2-75-473, at 7-9 (S.D. Ohio Sept. 16, 1976) (refusing to dismiss action charging state medical society and member doctors with fixing physicians' fees through their control of the state's largest Blue Shield plan); [1976] ANTITRUST \& TRADE REG. REP. (BNA) No. 753, at A-9 (as part of larger inquiry into competition in delivery and financing of health care services, FTC is investigating nature and extent of physician control of Blue Shield plans and its impact on fee levels and other forms of competition in delivery of health care). Cf. ABA Special Committee on Prepaid Legal Services, supra note 126, at $i$ ("the [prepaid legal service antitrust] problem narrows down to those plans whose control is vested in lawyers or designated representatives of an organized bar association"). 
the UCRF system employed by a provider-dominated service plan is subject to precisely the same objections as are FMCs' maximum fee schedules: they preclude competitive developments, substituting weak controls (if not totally ineffective or worse) for the robust controls that would emerge from active competition among HMOs and insurersponsored closed panels. ${ }^{161}$ So understood, professionally-sponsored prepayment plans, whatever the ostensible controls employed, are part of the medical profession's long struggle to prevent the emergence of innovations that serve the consumer's interest in cost containment. ${ }^{162}$ As such, a per se prohibition should be applied to all professionally sponsored efforts to regulate professional fees. As the Supreme Court stated in the Socony-Vacuum case,

[a]ny combination which tampers with price structures is engaged in an unlawful activity. Even though the members of the price-fixing group were in no position to control the market, to the extent that they raised, lowered, or stabilized prices they would be directly interfering with the free play of market forces. The Act places all such schemes beyond the pale and protects that vital part of our economy against any degree of interference. Under the Sherman Act a combination formed for the purpose and with the effect of raising, depressing, fixing, pegging, or stabilizing the price . . . is illegal per se. ${ }^{163}$

161. Professor Havighurst has termed the Blue Cross/Blue Shield organizational model "a cartel of fee-for-service providers." Havighurst, supra note 16, at 775 n.171. See Hearings on Competition, pt.2, at 1045 (statement of Professor Havighurst); H. SoMERS, \& A. SoMERS, supra note 9, at 296-97, 319, 324; Bodenheimer, Cummings \& Harding, Capitalizing on Illness: The Health Insurance Industry, 4 INT'L J. Health Services 583, 586, 588, 591 (1974).

The Blue plans resemble FMCs in that they usually try to obtain advance approval of provider groups to price discounts and other contract terms before issuing new policies. Blue Shield negotiates directly with medical societies and Blue Cross with hospital groups. Other insurers are not permitted to participate in these meetings and do not obtain the price discounts, any more than they gain the benefit of the relatively low fee rates set by FMC plans. And so the Blues, by maintaining their historically friendly relations with professional interest groups, continue to hold a dominant position in the health insurance market while setting the price floor for medical and hospital services. One would expect monstrous inefficiency in this system, and there is evidence of it. See [1977] ANTITRUST \& TRADE REg. REP. (BNA) No. 816, at A-12 (in 1969, hospital costs were $17 \%$ higher in areas where Blue Cross possessed monopoly power). In light of the substantial market power wielded by Blue Shield, see What's Blue Shield Up to Now?, Medical Examiner, Sept. 6, 1976, at 92, 94 (covers 35\% of U.S. population; 80\% of American doctors participate); [1976] ANTITRUST \& TRADE REg. REP. (BNA) No. 753, at A-9 (covers $90 \%$ of U.S. population), and Blue Cross, see S. LAw, supra note 9, at 1-2 (disburses about one-half the total money paid out for health care in America), it seems likely that competitive conditions will not exist in the health care services industry until provider domination of the Blue plans is ended. $C f$. Hearings on Competition, pt.2, at 1051 (statement of Professor Havighurst) (the Blue plans must be removed from their preferred position vis-à-vis the commercial insurer in dealing directly with doctors and hospitals before the commercials can effectively inaugurate cost controls).

162. See Note, The American Medical Association: Power, Purpose, and Politics in Organized Medicine, 63 YALE L.J. 938 (1954).

163. United States v. Socony-Vacuum Oil Co., 310 U.S. 150, 221-22, 223 (1940). 
Because professionally sponsored schemes, unlike insurer-initiated cost control programs, cannot claim dispensation under the ancillary restraint doctrine, Sherman Act principles, if applied, would condemn them. Thus, the ultimate question becomes whether the McCarran-Ferguson Act shelters professionally established fee controls from antitrust scrutiny.

\section{The McCarran-Ferguson Exemption and Professionally SPONSORED FEE SCHEDULES}

Despite their illegality under traditional antitrust analysis, FMCs and other provider-dominated insurance plans may contend that they are freed from antitrust scrutiny by the McCarran-Ferguson Act. ${ }^{164}$ The McCarran Act confers upon those engaged in the "business of insurance" a specific exemption from antitrust legislation to the extent that such business is regulated by state law. ${ }^{165}$ The exemption does not extend to predatory conduct arising from boycott, coercion or intimidation. ${ }^{166}$ Thus, fee schedule agreements would be excluded from the McCarran Act's protective umbrella if their formation and terms are not regulated by state law or if their implementation involves boycott, coercion or intimidation. More fundamentally, however, recent federal case law raises the question whether the "business of insurance" exemption applies to professional fee schedules. This section of the Article will discuss that case law and will conclude that the exemption should apply only to fee schedules imposed at the independent initiative of insurers, and not to fee arrangements that are created at the behest of providers of care, whether it be through provider sponsorship of the plan or through medical society domination or influence over the insurance plan.

Determining whether professional fee schedules fall within the definition of the "business of insurance" involves a choice between competing theories as to the proper scope of the McCarran Act exemption. Three possible definitions will be discussed here: first, the "business of insurance" covers only the underwriting of risk and the payment of indemnities, and not provision of products or services; second, the "business of insurance" includes only activities peculiar to the insurance industry; and finally, the "business of insurance" should be defined under a flexible test that parallels the doctrinal and policy considerations of the antitrust ancillarity principle. ${ }^{167}$

164. 15 U.S.C. $\S \S 1011-1015$ (1976).

165. Id. $\S 1012(\mathrm{~b})$.

166. Id. \& 1013(b).

167. The definition of the phrase "business of insurance" as it is used in the McCarran Act is 
The Supreme Court in SEC v. Variable Annuity Life Insurance $C o{ }^{168}$ broadly defined the "business of insurance" as the underwriting of risks in exchange for a premium. In a considerable narrowing of this definition, the Fifth Circuit Court of Appeals in Royal Drug recently decided that the business of insurance comprehends indemnifying insureds for their losses but does not include providing products and services. ${ }^{169}$ This ruling ran against the precedent of several district court decisions ${ }^{170}$ and appeared inconsistent with the leading Third Circuit case of Travelers Insurance Co. v. Blue Cross. ${ }^{171}$ The Royal Drug court simply disapproved of the rationale behind the various district court holdings. Taking particular aim at Manasen v. California Dental Services, ${ }^{172}$ a district court decision involving a prepaid dental program, the court argued that services did not become transformed into "insurance" solely because they have "an impact, favorable or otherwise, upon premiums charged by the insurer." 173 The court distinguished Travelers on the ground that that case had involved a unique situation in which the Insurance Commissioner of Pennsylvania had

a matter of federal statutory construction and should be decided by reference to federal law. In Pastor v. Hartford Fire Ins. Co., 1976-1 TRADE CASES (CCH) I 60,783 (C.D. Cal. 1976), the opposite position was adopted, the court holding that a commercial insurer was entitled to the McCarran exemption from the antitrust laws because its activities were within the state of California's definition of insurance, but that the business of a county medical association, which was not encompassed by the state's definition, was outside the protective scope of the McCarran Act. This reasoning confuses the question of the meaning of "insurance" with the analytically separate problem of defining the scope of a given state's regulation of insurance. The existence of state regulation is a discrete requirement under the McCarran-Ferguson Act that should be kept separate from the threshold issue of defining the business of insurance. The Supreme Court has explicitly stated in SEC v. Variable Annuity Life Ins. Co., 359 U.S. 65, 69 (1959), that "the words 'insurance' and 'annuity' are federal terms" for McCarran Act purposes; lower courts should adhere to that rule and not inject confusion into this already complex area by intermixing the problem of defining insurance with the problem of interpreting the contours of state regulation.

168. 359 U.S. 65,71 (1959).

169. 556 F.2d at 1381-82. The facts are discussed at notes 117-18 supra and accompanying text. The court's holding is less than clear, however, since in ruling that Blue Shield's drug plan was not within the protection of the McCarran Act it also relied on the absence of state regulation of the fee schedules involved, on the coercive aspects of the plan and on its effect as a horizontal, anticompetitive restraint on prices.

170. See Manasen v. California Dental Serv., 424 F. Supp. 657 (N.D. Cal. 1976); Proctor v. State Farm Mut. Auto. Ins. Co., 406 F. Supp. 27 (D.D.C. 1975); Schwartz v. Commonwealth Land Title Ins. Co., 374 F. Supp. 564 (E.D. Pa. 1974); Nankin Hosp. v. Michigan Hosp. Serv., 361 F. Supp. 1199 (E.D. Mich. 1973); California League of Independent Ins. Producers v. Aetna Cas. \& Surety Co., 175 F. Supp. 857 (N.D. Cal. 1959). Two such decisions have been affirmed on appeal. Anderson v. Medical Serv. of the Dist. of Columbia, 551 F.2d 304 (4th Cir. 1977); Frankford Hosp. v. Blue Cross, 554 F.2d 1253 (3d Cir.), cert. denied, 434 U.S. 860 (1977). See also Proctor v. State Farm Mut. Auto. Ins. Co., 561 F.2d 262, 268 (D.C. Cir. 1977).

171. 481 F.2d 80 (3d Cir.), cert. denied, 414 U.S. 1093 (1973).

172. 424 F. Supp. 657 (N.D. Cal. 1976).

173. Royal Drug, 556 F.2d at 1386. 
exerted pressure on insurance companies to exercise their power over hospitals to reduce hospital costs. Though Royal Drug did not cite Parker v. Brown, ${ }^{174}$ its interpretation of Travelers appears to follow Parker's holding that the Sherman Act does not invalidate state regulation of economic activity. The court reasoned that insofar as the state of Pennsylvania, acting through its insurance commissioner, was regulating hospitals through the medium of insurance companies, the activities of those companies represented extensions of state activities and therefore were not subject to the Sherman Act. ${ }^{175}$

Whether Travelers can be fairly distinguished on state action grounds or not, the fact remains that, with the exception of Royal Drug, the federal courts have uniformly refused to deny McCarran Act application to activities of professional service plans merely because they involve the delivery of products and services rather than simple indemnity. This approach is proper; the definition of "insurance" should not turn mechanically on whether a given plan technically provides service or indemnity. Many of the closed panel service plans supported by this Article as procompetitive innovations in the health insurance industry would be denied protection as insurance under this formalistic approach; a more flexible test is needed.

A second possible definitional formulation for the "business of insurance," also suggested in Royal Drug, is whether the activity in issue is "peculiar to the insurance industry."176 Under this definition, activities not unique to insurers would not qualify under the McCarran Act. This notion draws some support from the legislative history of the Act. Until 1944, insurance contracts were deemed outside the constitutional reach of federal legislation because they did not concern interstate commerce. When that doctrine was reversed by United States $v$. SouthEastern Underwriters Association, ${ }^{177}$ Congress was suddenly faced with the potentially chaotic intrusion of the Sherman Act into an area that had traditionally been the special concern of the states. It reacted by passing the McCarran Act. There is little dispute that the Act was passed for the benefit of insurance companies and that Congress' concept of "insurance" was that derived from the conventional gloss that

174. 317 U.S. 341 (1943). See also Cantor v. Detroit Edison Co., 428 U.S. 579, $592-98$ (1976) (for state economic regulation to exempt business from Sherman Act, the regulation must be narrowly defined, specific and necessary to the state's purpose).

175. See 556 F.2d at 1382-83. The Fifth Circuit derived support for this interpretation of Travelers from Doctors' Hosp. v. Blue Cross, a Pennsylvania case later affirmed per curiam by the Third Circuit. 360 F. Supp. 693 (E.D. Pa. 1973), affd per curiam, 535 F.2d 1245 (3d Cir. 1976).

176. $556 \mathrm{~F} .2 \mathrm{~d}$ at $1383-84$.

177. 322 U.S. 533 (1944). 
the term had acquired under state law. ${ }^{178}$

As in the case of the services-indemnity dichotomy, however, the "peculiar to the insurance industry" test proves too much. It, too, indiscriminately pulls within its sweep many insurer-initiated cost controls that are procompetitive and that clearly relate to the terms of insurance contract coverage. What is within the legitimate ambit of the insurance industry must change with the needs of society; the service of cost containment may be a novel insurance activity, but it is also an activity ideally suited to insurers - an activity that competitive forces, had they been allowed to work freely in the health sector, might have produced long before. Moreover, the "peculiar to the insurance industry" test appears to be narrower than that called for by the Supreme Court's language in SEC v. National Securities, Inc., ${ }^{179}$ an important case extensively relied upon in Royal Drug. ${ }^{180}$ In National Securities, the Court included within the "business of insurance" the "relationship between insurer and insured," the "type of policy which could be issued, its reliability, interpretation, and enforcement," and "other activities ... [which] relate . . . to their status as reliable insurers." ${ }^{181}$ These criteria are broad enough to embrace activities that noninsurers might also be engaged in.

The definition of the "business of insurance" should be a flexible test that accounts for the purposes of both the McCarran and the Sherman Acts. Congress did not intend by its passage of the McCarran Act to unleash and protect anticompetitive activities that would normally be proscribed by the Sherman Act any time that those activities can be superficially characterized under the rubric of "insurance." On the other hand, Congress certainly did not attempt to meticulously define the limits of the insurance business, nor did it intend to freeze evolution of the insurance industry as it existed at the Act's passage. It is perfectly consonant with the purposes of the antitrust laws and the McCarran Act to give antitrust exemption to insurer-initiated fee schedules when insurers stand in a position basically antagonistic to providers and negotiate with providers solely to lower the costs at which they can offer service to their subscribers. This type of cost-control activity is procompetitive-vindicating the purposes of the Sherman Act-and it enhances the insurance carriers' business, thereby aiding the very parties

178. As the Supreme Court has stated, "Congress was legislating concerning a concept which had taken on its coloration and meaning largely from state law . . ." SEC v. Variable Annuity Life Ins. Co., 359 U.S. 65, 69 (1959).

179. 393 U.S. 453 (1969).

180. See 556 F.2d at 1380.

181. 393 U.S. at 460. 
that the McCarran Act was designed to protect. If there are indications of monopsony power and its abuse, of course, the courts should give even insurer-initiated fee controls close scrutiny. ${ }^{182}$

Fee schedules created by provider-dominated plans-either Blue plans or separate provider-sponsored entities-call for the opposite result. Provider dominance, for reasons discussed at length earlier in this Article, is inherently anticompetitive. Fee schedules fixed at the behest of providers invariably form the basis for increases in prices and they smack of blatant horizontal restraint. In the case of Blue plans, provider influence may have the effect of co-opting innovation by setting up barriers to the entry of alternative delivery and pricing models.

This analysis is consistent with much of the tenor of the Royal Drug opinion, though it would require a more searching treatment of the competing factors than the Fifth Circuit undertook. The court in that case found elements of coercion in the prepaid drug plan that Blue Shield designed, and coercion, under the explicit language of the McCarran Act, would render an activity subject to antitrust scrutiny. The court also appeared to be influenced by traces of horizontal combination in the record. When a horizontal agreement, of either an explicit or "conscious parallelism" variety, coercion or other evidence of provider overbearance is present, the Royal Drug result should be emulated.

Finally, it should be observed that this analysis of the McCarranFerguson Act closely parallels the scope of the ancillarity doctrine previously discussed. Cost controls which are reasonably related to a legitimate commercial purpose and which are no more restrictive than necessary to effectuate that purpose should be encouraged, not discouraged, by the antitrust laws. The parallel to the ancillarity doctrine suggests a corollary to the McCarran Act analysis contained here: when a less restrictive alternative is available to accomplish an insurer's cost containment ends, that alternative should be required in order to gain the McCarran Act's shelter. In the case of a closed-panel medical plan, for example, subscribers should have the option of receiving care from physicians not participating in the panel, to be reimbursed at a fixed lesser percentage of that physician's charge. Alternatively, the subscriber might be required to pay the nonparticipating physician the difference between his fee and the closed-panel fee; the physician would then be directly reimbursed by the plan at the plan's normal fee rate. These models would introduce price competition among providers and therefore deserve judicial approval.

182. See notes $71 \& 72$ supra. 
Conceptually, of course, approval might come either by including such plans within the "business of insurance" definition or by denying McCarran Act protection, but recognizing the ancillarity argument as an affirmative defense. Because antitrust principles would tolerate medical care fee schedules introduced by commercial insurers whether or not the schedules fall within the protective provisions of the McCarranFerguson Act, it is ultimately irrelevant to the legality of such schedules whether the Royal Drug court was correct in refusing to consider them the "business of insurance." Nonetheless, the court was probably wrong in not recognizing cost control implemented through fee schedules to be a legitimate part of the insurance business.

In sum, a sound definition of the McCarran Act's "business of insurance" would exempt fee schedules from antitrust scrutiny so long as they are not provider-dominated plans. This definition effectuates the purposes of both the McCarran Act and the Sherman Act, and enhances the laudable social goal of cost containment within the health sector.

\section{Relative Value Schedules: A Permissible Approach to Health Care Cost Control}

\section{A. Why Relative Value Schedules Are Desirable.}

One issue which is vital to the development of insurer-initiated cost control contracts is whether relative value schedules should be condemned under the Sherman Act as price fixing instruments. The relative value schedule is a price data dissemination device virtually unique to the medical profession. ${ }^{183}$ It compares the relative median charge values of specified physician or hospital services as they are actually being charged in a discrete geographical area. Applying a monetary conversion factor to the relative value of a given procedure determines its price. ${ }^{184}$

183. See, e.g., California Medical Association, supra note 2. See also National AssoCiation of Blue Shield Plans, supra note 2. Relative value schedules have been designed and used primarily by physicians, but they seem equally desirable and viable in the hospital context. See Kovener, Relative Value Scheduling: $C F+1$, Hosp. Accounting, Sept. 1967, at 15.

The relative value device has been adopted by only one state bar association, that of Kansas. See Corley \& Arnould, supra note 43, at 22-26. Some persons have expressed interest in using value guides more widely in pricing legal services. See generally Blaine, supra note 4. Use of a relative value schedule by one bar-sponsored prepaid legal services plan has met antitrust opposition. See notes 131-36 supra and accompanying text.

184. See California Medical Assoclation, supra note 2, at 7, 119; Blaine, supra note 4, at 1007-09. 
Relative value schedules are desirable in the context of health care cost control because they would be the basis for bargaining between insurers and providers of care. They constitute a tool which has proven effective in retarding medical care cost inflation. ${ }^{185}$ Insurers have already begun to rely upon these schedules in cost control programs ${ }^{186}$ and it seems clear that they will have continuing incentive to design and utilize accurate value scales in the future. By varying the conversion factors according to a provider's expertise or technological capability with respect to particular services, the insured's willingness to pay and its own claims-handling efficiency, an insurance company could offer a wide variety of price-service packages to both subscribing consumers and participating providers. For this reason, relative value scales "provide a potential instrument for equitable and professionally acceptable regulation of health care costs." 187

It is important to note that relative value schedules, utilized in this way, do not fix prices. Although relative value schedules serve some of the desirable purposes supposedly attained by minimum fee schedules, especially the dissemination of price information to new practitioners and consumers, ${ }^{188}$ they are not fee schedules as such because no price is fixed until a conversion factor is applied. Therefore, relative value scales do not create the antitrust concerns which have arisen with respect to the fee agreements that may ultimately be reached between insurers and providers.

Nevertheless, the federal antitrust agencies have mounted a concentrated attack upon relative value schedules as they are currently being utilized by medical societies. The remaining parts of this section of the Article will discuss that attack and demonstrate that the antitrust objection applies to the promulgation and dissemination of value scales by professional associations rather than to the scales themselves. It will be concluded that the Sherman Act will not prohibit the use of relative

185. See HEW Public Health SeRvice, supra note 6, at 34 (1976).

186. See California Medical Association, supra note 2, at 6; Carlova, supra note 3, at 31, 36; Council on Wage and Price Stability, supra note 10, at 40, 317-18; cf. Egdahl, supra note 144 , at $492,495$.

Insurers of professional services in foreign countries have also found fee schedules indispensable in controlling costs. See Pfennigstorfl, Legal Expense Insurance, 23 AM. J. CoMP. L. 451, 466 (1975).

187. H. SOMERS \& A. SOMERS, supra note 9, at 424; see id. at 55; Bibler, What Relative Value Studies Mean to the General Practitioner, 1959 J. IND. ST. MED. A. 1340, 1344-45. Cf. Kovener, supra note 183, at 17.

188. See Bibler, supra note 187, at 1345; Comment, Legal Fee Schedules: New York's Approach, 24 Buffalo L. Rev. 839, 854 (1975); Note, A Critical Analysis Of Bar Association Minimum Fee Schedules, 85 HARv. L. REv. 971, 986-87 (1972). 
value studies by insurance firms for cost control purposes unless the result is price uniformity.

\section{B. Antitrust Attack on Medical Society-Designed Relative Value Schedules: The Trade Association Cases.}

In the wake of the Goldfarb decision, the Federal Trade Commission (FTC) and the Antitrust Division of the United States Department of Justice have been vigorously attacking relative value schedules promulgated by various medical societies. ${ }^{189}$ The FTC has entered consent agreements with several associations of health care professionals abolishing the use of such schedules ${ }^{190}$ or ordering the retraction of previously issued schedules. ${ }^{191}$ Meanwhile, the Antitrust Division has filed civil actions against other medical associations, charging them with price fixing through the use of relative value schedules and seeking to enjoin their further use. ${ }^{192}$ In the face of this antitrust pressure, several state medical societies have voluntarily abandoned the use of relative value scales. ${ }^{193}$

The government has taken the position in these cases that the compilation and promulgation of relative value guides by providers acting in combination through their medical societies constitutes impermissible meddling with the medical service price structure. Apparently recognizing the important interests that relative value schedules can serve when used appropriately, ${ }^{194}$ the antitrust enforcement agencies have

189. See Doctors and Lawyers Fight the Madison Avenue Route, 8 NATIONAL J. 1144, 1147-48 (1976), summarizing the activities of the FTC and the Antitrust Division against restrictive practices of the medical industry. The FTC is particularly active in this area.

190. See Specialties Abandon Value Scales, Am. Med. News, July 26, 1976, at 1, col. 4 (American Academy of Orthopedic Surgeons and American College of Obstetricians and Gynecologists). FTC consent orders do not require any admission of wrongdoing. See also [1977] ANTITRUST \& TRADE REg. ReP. (BNA) No. 797, at A-10 (FTC has charged American Dental Association with an illegal restraint of trade in violation of the FTC Act by preventing price competition through its ethical codes; FTC asks for prohibition against publication or enforcement by ADA of any agreement, ethics code or interpretation that would restrain competition among dentists).

191. See Medical Association in Minnesota Agrees to Bar on Fee Codes, Wall St. J., Apr. 21, 1977, at 14, col. 3 (Minnesota State Medical Association and 34 local medical societies); Radiologists Accept FTC Order Barring Pricing Schedules, Wall St. J., Nov. 18, 1976, at 12, col. 3 (American College of Radiology).

192. United States v. Illinois Podiatry Soc'y, Inc., No. 77 C501 (N.D. Ill., filed Feb. 14, 1977), cited in [1977] ANTITRUST \& TRADE REG. REP. (BNA) No. 801, at A-25; United States v. American Soc'y of Anesthesiologists, Inc., Civil No. 75-4640 (S.D.N.Y., filed Sept. 22, 1975), cired in 4 TRADE REg. Rep. (CCH) If 45,075, at 53,623. See also United States v. Alameda County Veterinary Medical Ass'n, Civ. No. 75-2398-CBR (N.D. Cal, filed Aug. 8, 1977) cited in [1977] ANTITRust \& TRADE REg. ReP. (BNA) No. 826, at A-10.

193. See Carlova, supra note 3 , at 42.

194. See notes $63 \& 74-77$ supra and accompanying text. 
not sought to prevent individual physicians from using the schedules, nor have they acted against third party groups which design and employ them. ${ }^{195}$ The goal, rather, is to prevent professional organizations from interfering with the fee-setting practices of members. ${ }^{196}$

The government seems to have taken the position in these cases that medical associations should be regarded as trade associations for antitrust purposes and that the principles derived from trade association cases should be applied to the price determining activities of medical societies. This position makes sense in that medical associations, like ordinary business trade associations, represent and act to further the collective interests of the professional membership. ${ }^{197}$

Medical society compilation and updating of relative value schedules resemble several forms of trade association price formula activities which have been found subject to challenge as price fixing under the Sherman Act. ${ }^{198}$ For example, "basing point" pricing-where an association gathers and publishes average production cost data and standard transportation rates ${ }^{199}$ or where it disseminates a price study

195. Some Blue plans use relative value scales in negotiating service plans with providers, see note 185 supra.

196. See authorities cited in note 192 supra.

197. See Meeks 875-76, for analogous discussion of bar associations as trade associations. The medical profession differs from many other trades because of the substantial market power, bordering on monopoly power, which every doctor and hospital wields in dealing with the consuming public. See Hearings on Competition, pt.2, at 1039 \& 1580-84; S. LAw, supra note 9, at 3233 \& 38-41; Havighurst, HMO's 768-69; Kessel, supra note 60. Medicine is also distinguished from other industries on the ground that concentration among doctors and hospitals is infrequent except on a very local level. Cf. Comment, Bar Association Minimum Fee Schedules and the Antitrust Laws, 1974 Duke L.J. 1164, 1178.

Nevertheless, professional organizations in the health care sector resemble ordinary trade associations in that they represent and act to further the collective interests of the professions. Hospitals and medical societies do in fact powerfully reinforce and maintain the market power of individual providers of care. See Havighurst, HMO's 768-69; Kessel, supra note 60; Kessel, The A.M.A. and the Supply of Physicians, 35 LAW \& CONTEMP. PROB. 267 (1970); Rayack, Restrictive Practices of Organized Medicine, 13 ANTITRUST BuLl. 659 (1968); Comment, The American Medical Association: Power, Purpose, and Politics in Organized Medicine, 63 YALE L.J. 937 (1954). See generally E. RAYACK, Professional Power and ORGanized MEdicine (1967). It has been suggested that, in a subtle fashion, the very independence and power of their members makes these organizations even more dangerous than traditional trade associations because anticompetitive practices can be maintained within them with fewer formalities than is usually the case. Havighurst, HMO's 768.

198. For recent discussions of case law on trade association pricing activities, see Kefauver, The Legality of Dissemination of Market Data by Trade Associations: What Does Container Hold?, 57 CoRnell L. Rev. 777 (1972); Comment, supra note 197, at 1174-79; Note, Antitrust Implications of the Exchange of Price Information Among Competitors: The Container Corporation Case, 68 MiCH. L. REv. 720 (1970).

199. See Maple Flooring Mfrs. Ass'n v. United States, 268 U.S. 563 (1925). In Maple Flooring, the Supreme Court upheld the price reporting plan despite the fact that the association's twenty-two members represented seventy-five percent of industry production, relying on the gov- 
matching the values of the different types or sizes of a complicated product to a standard value ${ }^{200}$-is unlawful under section one. Price "manuals" that enable the individual seller to convert "fragmentary" price data from his competitors into meaningful price statistics have been held illegal. ${ }^{201}$ In general, any common costing method proposed by a trade group and enforced by a system of penalties-and the penalties may be as mild as "social pressures"202 -raises antitrust problems. ${ }^{203}$

The problems arise because price information activities of trade associations tend, whatever their ostensible purpose, to promote price uniformity. ${ }^{204}$ Due to the central and commanding market position occupied by a medical society, ${ }^{205}$ competing value scales are discouraged and providers are exhorted by the social pressures of the profession to design charges in accordance with the society's value schedule. ${ }^{206}$ The compilation and presentation of these schedules at medical society meetings facilitates the stabilization of prices because a provider can pigeonhole his charge schedule by mentioning a couple of past charges or by referring to his conversion factor ${ }^{207}$ and because an upward adjustment in the value of any service would result in an across-the-board increase in its price. ${ }^{208}$ It might be difficult to prove at trial that prices

ernment's failure to prove either an anticompetitive purpose or an actual restraint of trade. Id. at 583-86. The case is hard to reconcile with subsequent decisions holding that purpose is irrelevant and that illegal effect can be presumed from price information dissemination schemes in an oligopoly setting. See United States v. Container Corp. of America, 393 U.S. 333 (1969); Sugar Inst., Inc. v. United States, 297 U.S. 553 (1936). See also C. WILcoX, CoMPETITION AND MoNOPOLY IN AMERICAN INDUSTRY 232 (TNEC Monograph No. 21, 1941).

200. See United States v. United States Steel Corp., 223 F. 55, 154-61, 173-77 (D.N.J. 1915), affd, 251 U.S. 417 (1920); C. KAYSEN \& D. TURNER, supra note 65, at 149.

201. See United States v. Container Corp. of America, 393 U.S. 333, 336 (1969).

202. See American Column \& Lumber Co. v. United States, 257 U.S. 377, 399 (1921). See note 206 infra and accompanying text.

203. See C. Wulcox, supra note 199, at 228 \& 230. Professional codes of ethics can provide a potent vehicle for subtly imposing such penalties. See id. at 232. Cf. Goldfarb v. Virginia State Bar, 421 U.S. 773, 781-83 (1975).

204. See United States v. Container Corp. of America, 393 U.S. 333, 336-37 (1969).

205. See, e.g., United States v. Illinois Podiatry Soc'y, Inc., [1977] ANTITRUST \& TRADE REG. REP. (BNA) No. 801, at A-25 (N.D. Ill) (representing $60 \%$ of Illinois podiatrists); United States v. American Soc'y of Anésthesiologists, Inc., 4 TRADE REG. REP. (CCH) \ 45,075 (S.D.N.Y. 1975) (representing 90\% of American anesthesiologists). Cf. Meeks 878.

206. For an example of similar pressures to conform in trade organizations, see American Column \& Lumber Co. v. United States, 257 U.S. 377, 399 (1921) ("open competition" plan designed by hardwood producers' association was unlawful where it ensured "harmony" of prices through a system of "trade punishment" maintained by "social pressures").

207. See [1977] ANTITRUST \& TRADE REG. REP. (BNA) No. 803, at A-20, citing a statement by an FTC spokesperson that relative value scales are suspect because they can easily be used to set prices.

208. There is suspicion that the biases of medical society compilers tend to inflate the rela- 
are in fact illegally stabilized in these ways. But such proof may be unnecessary because the courts will presume an illegal effect from the mere flow of specific price information among competitors in an industry possessing the competition-discouraging structural characteristics of the medical profession, ${ }^{209}$ such as inelastic demand ${ }^{210}$ and high entrance requirements. ${ }^{211}$

The compilation of relative value data by medical societies offends the Sherman Act because it requires the exchange of specific price information among competitors and tends to stabilize the prices of medical care in the affected community. Little would be lost and much might be gained by forbidding this activity as per se illegal under the Sherman Act. Providers will have to make charges with less sure knowledge of the price structures utilized by other providers, but this fact of life will improve competition, not defeat it. The sincerity and accuracy of some professionally designed relative value studies would be sacrificed, but equally reliable schedules can be drafted by competing insurers engaged in arm's length bargaining with providers of care. Since no exigency appears which can justify professional participation in preparing and promoting relative value schedules, ${ }^{212}$ a rule condemning it seems appropriate. ${ }^{213}$

tive values of specific services upward. See Carlova, supra note 3, at 42; Edlund, supra note 64, at 800 (Blue Shield distrust of medical society committee designed value scales).

209. United States v. Container Corp. of America, 393 U.S. 333, 337 (1969). See United States v. Socony-Vacuum Oil Co., 310 U.S. 150, 221-222 (1940); Note, supra note 198, at 727-28.

210. Where demand is inelastic-that is, where it does not diminish as prices rise and increase as prices fall-a price reporting plan can be expected at best to yield stable, but not lower, fees. C. WILcoX, supra note 199, at 229.

211. Where, as in the medical and hospital fields, entrance to the industry is limited by legal impediments such as education and accreditation requirements or by the need for a large capital investment, a reporting system can in itself "implement a price agreement, or promote price leadership and facilitate the application of pressure against price cutters." $I d$.

212. In the analogous field of lawyers' fees, the Antitrust Division has hesitated to bless bar association-sponsored relative value studies even when prepared by an independent organization, see notes 131-36 supra and accompanying text, and it has permitted bar involvement in fee setting only as necessary to the inauguration of a consumer-controlled fee restrictive prepaid service plan, see notes 141-42 supra and accompanying text. Even that much involvement is unnecessary in the sphere of health care financing because of the years of actuarial fee data that insurance carriers have accumulated and because of the relative value schedules which are already in use.

213. United States v. Container Corp. of America, 393 U.S. 333 (1960), struck down an agreement by the eighteen suppliers of $90 \%$ of America's corrugated cardboard boxes to furnish each other, upon request, the most recent prices charged or quoted to a specific customer. The record showed that such requests were infrequent and irregular, and there was little evidence of anticompetitive purpose or effect. The case seemed to raise a presumption that the flow of specific present price information in a structural oligopoly would lead to interdependent pricing. See Kefauver, supra note 198, at 786-87. The Supreme Court used some per se language in the Container case, 393 U.S. at 336-67, but its result was not reached by per se reasoning. See, e.g., Kefauver, supra note 198, at 784-87 \& n.45, 791-92; Comment, supra note 197, at 1178 \& n.91; Note, supra note 198, at 730-32 \& 737; $c$. United States v. Citizens \& S. Nat'l Bank, 422 U.S. 86, 


\section{Relative Value Schedules Designed by Insurers-A Permissible Alternative.}

The most practicable alternative to provider-promulgated relative value schedules is to have third party payors design them. ${ }^{214}$ Insurers can base the schedules on their own claims experience ${ }^{215}$ and, at least

113 (1975). Instead, the Court implied that a defense of justification, such as was raised successfully in Cement Mfrs. Protective Ass'n v. United States, 268 U.S. 588 (1925), could still be used to legitimize price exchanges among competitors. See Container, 393 U.S. at 335.

In Cement Manufacturers, the Court upheld as an ancillary, reasonable restraint an exchange among cement manufacturers of "specific job contract" information including prices, amounts and names of purchasers. Under such contracts, which were standard in the industry, the contractor got an option to purchase at a stated price all the cement he needed for a specific job; the price would follow the market if it declined but the supplier was bound if it rose. The Court agreed with the defendants that the data exchange was justified by the need of manufacturers to protect themselves from the fraudulent practice of some contractors who would purchase at a low price much more cement than was needed for a specific job, then use it on other jobs. Id. at 59496. See also United States v. United States Gypsum Co., 550 F.2d 115, 123 (3d Cir. 1977), cert . granted, 98 S.Ct. 52 (1977); Webster v. Sinclair Ref. Co., 338 F. Supp. 248, 250-51 (S.D. Ala. 1971).

No such justification seems likely to arise in the health insurance market. Insurer-provider contracts will probably be of one or more years in duration, so as to assure stability, rather than handled on a "job" basis. Providers will have numerous fee proposals, offered by competing insurers, from which to choose. Therefore "fraudulent" behavior by insurers negotiating for low fees does not promise to be a problem.

214. Other alternatives would include having a government agency design the value scales, or engaging an independent outside organization to do so. There is, of course, currently no government agency with the authority and interest to collect medical and hospital fee data and compile a relative value statistical study. HEW has some expertise in this area due to its studies of relative value schedules; Health Systems Agencies would be another candidate for the job due to their local practice orientation. To undertake such a task would be an ongoing, expensive and time-consuming proposition, for it would entail continuous review of the costs and historical price structure of a multitude of practice communities nationwide. The primary advantage of a governmentally conducted relative value study would be, in theory at least, its objectivity. But both insurers and providers of care might understandably object to this additional intrusion of the regulatory bureaucracy into their affairs. More importantly, the governmental approach would result in only one relative value scale in each market area, thus perpetuating that lack of diversity which is thought to be one of the chief failings of the present system of professionally designed scales.

The private, independent organization approach to conducting relative value studies seems less workable even than the governmental approach. If the organization were engaged by either provider or insurer interests, the cost might be greater than if the interested party had conducted the study itself, and the fear of bias would still be present.

215. See note 182 supra and accompanying text. Apparently the Blues have had this capability for years, see note 121 supra, but sometimes merely in the role of an ersatz medical society, see Edlund, supra note 208. Others have apparently had success working with providers and with computerized claims data to prepare fee schedules for company use. See Pettengill, No Perfect Plan, 9 Trial 21, 22 (Mar./Apr. 1973) (Aetna Casualty and Insurance Co.). Cf. Edlund, supra note 208 , at 800 (suggesting that insurers could design a more practical, actuarially-oriented relative value schedule than providers, interested simply in setting a fee, have done). See also Rosenberg, supra note 23, at 33, 36 (Aetna Life \& Casualty Co. was apparently able to develop computerized fee profiles for cost control purposes in 1972 from medical society relative value studies and its own records of providers' past charges). But see Bailey, supra note 24, at 609; 
initially, on relative value studies previously made by medical associations. ${ }^{216}$ They can count on participating providers to help keep the schedules up to date by advising them of areas where old records are out of line with current costs. An insurer could ensure the accuracy of its schedule and any requested cost increases by comparing cost charges suggested by providers in one community with those reported in other areas in which it does business.

Insurer-designed relative value schedules would escape the antitrust problems posed by medical society-sponsored schedules because they would be diverse. Since each insurance firm would have its own relative value guide based upon its own claims history, the problems posed by price data exchanges among competitors would not arise. Moreover, an insurer might well apply varying conversion factors to its schedule in making fee arrangements with different providers of care. Hence, one would not expect the schedules to result in uniformity of prices. If excessive uniformity did in fact result, this would of course be cause for antitrust concern, but that concern would focus not upon the relative value schedule as a price fixing device but upon its improper manipulation for the purpose of price fixing by a combination of insurers or providers or upon its unlawful use by a monopsonist insurer.

Nor, as utilized by individual insurers as a means of setting fees in contracts with individual providers, should relative value schedules be held to offend the prohibition against price fixing. Such contractual arrangements can be saved under the ancillarity doctrine, the McCarranFerguson Act or the rules relating to maximum fee restraints discussed above.

\section{CONCLUSION}

Commercial insurance companies, when challenged to play a more aggressive role in containing the rising costs of medical care by negotiating fee controls with providers, have responded that the antitrust laws will preclude them from doing so unless a specific legislative dispensation is made. ${ }^{217}$ This Article has demonstrated that no such

Carlova, supra note 3, at 35, 36; What Price Health Care? The Problem of Cost Containment, supra note 24 , at $42,43$.

216. For this purpose, the discarded relative value studies of medical associations would constitute "purely advisory guidelines" not restraining trade within the meaning of Goldfarb. See notes 52-55 supra and accompanying text. Cf. Cohen, State Rate Regulation, in CoNFERENCE oN REgULATION IN THE HEALTH INSURANCE INDUSTRY OF THE INSTITUTE OF MEDICINE OF THE National ACademy of Sciences, Controls on Health Care 123, 129 (1975) (head of Maryland's hospital rate-setting commission uses relative value schedules in setting initial rates but may not need a schedule after that).

217. See, e.g., Bailey, supra note 24, at 609; What Price Health Care? The Problem of Cost 
exemption is necessary. The McCarran-Ferguson Act, properly construed, already shields fee agreements between individual insurers and individual providers from Sherman Act scrutiny. Even if the McCarran legislation were read so as not to exempt such agreements, traditional antitrust principles relating to maximum fee schedules and ancillary restraints of trade would encourage, rather than denounce, insurer-provider cost control contracts. What neither the McCarran Act nor antitrust doctrine should be held to allow is the participation of organized medicine or other provider groups in the design and negotiation of these contracts. With the air cleared of anxiety about Sherman Act implications, it is urged that the commercial insurance industry act, before overly-hasty regulation of the health services market prevents it, to show that private third party payors can put controls on medical costs and in so doing benefit not only themselves but the nation.

Containment, supra note 24, at 41-43. Cf. Hearings on the Commercial Health and Accident Insurance Industry Before the Subcomm. on Antitrust and Monopoly of the Senate Comm. on the Judiciary, 92d Cong., 2d Sess., pt. 1, at 1304 (1972); id, pt. 2, at 170 (Senator Kennedy offers antitrust exemption to enable insurers to combine to exert leverage on medical profession to force cost controls). 
' 